\title{
تصور مقترح لتحسين أداء البرامج الرياضية فى القناة الثامنة

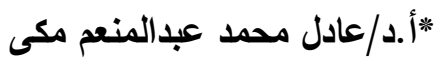

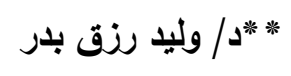

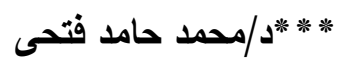

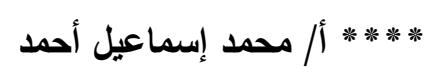

\section{المقدمة ومشكلة البحث}

يعد التليفزيون من أهم وسائل الإعلام المختلفة حيث يعد وسيطا ثقافيا و

قوة تربوية تعمل كمصدر للمعرفة و ذلك لما له من خصائص ومميزات ينفرد بها لدى له الجمهور حيث أنه يجمع بين الصوت والصورة واللون في آن واحد وهذا كله له تأثثر دير كبير على الثخص المشاهد له فيفرض المادة التي يقدمها على الصغار و الكبار مما بسهم في تكوين الثخصية المتكاملة ويستطيع التليفزيون أن يشكل نوعية جديدة من المواطنين و أن يغير أبعاد مشاركة المواطنين في الحياة الاجتماعية بالاستعانة بما يقدمه التليفزيون من الحقائق والمعلومات ـ ( (Y:r)

ومن خلال هذة الوسيلة يعتبر الإعلام منهج وعملية يقوم على هدف التتوير و

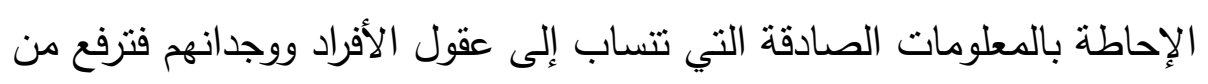
مستواهم و تدفعهم إلى العمل من أجل المصلحة العامة و تخلق فيما بينهم مناخا يقظا يمكنهم من الانسجام و الحركة البسيطة و من ثم فإن الإعلام على هذا النحو يعد عملية ووظيفة اجتماعية تهف إلى تتوير الرأي العام للوصول إلى أفضل النتائج .

$$
(r \cdot-r V: r V)
$$

فالإعلام الذى يقدمة التلفزيون وخاصة الرياضي له دور متشعب في المجتمع

و لذلك أجمعت الحكومات رغم اختلاف سياستها الفكرية أن تخصص له الصحف و القنوات الإذاعية و التليفزيونية و توجهها نحو تحقيق أهدافها الداخلية والخارجية وأيضا 
زيادة الوعي الرياضي للمجتمع و تعريفه بأهمية دور الرياضة في حياتهم العامة و

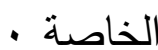

لذا يمكن القول بأن وسائل الإعلام المتعددة تهدف إلى توعية وتثقيف مختلف مستويات

* عميد كلية التربية الرياضية-الأستاذ بقسم الإدارة الرياضية والترويح- جامعة أسوان

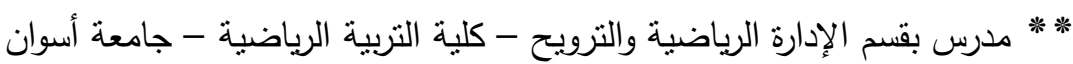

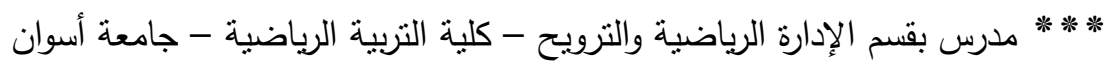
***** كبيرمخرجين بالقناة الثامنة بالتليفزيون المصري- الباحث بدرجة الدكتوراة

المجتمع التي تتابع ما ترسله من برامج فتؤثز بقوة في تشكيل أسلوب حياة الأفراد كما أن تطور تلأك الوسائل بساعد في نشر الوعي والثقافة الرياضية و تبادل الخبرة والمعلومات و بالتالي تقدم المجتمع.(r: • ^)

ويـرى البـاحثين أن التليفزيـون أصـبح قـوة كبيـرة تـؤثر فـي الفـرد والمجتمـع

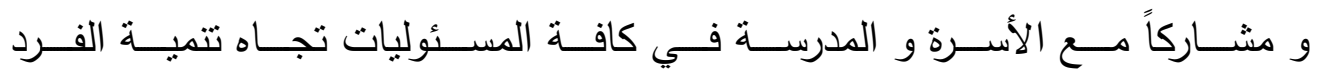
والمجتـع ويمكـن مـن خــلال التليفزيـون الإسهـام بـدور إيجـابي في توجيـه قدرات الفـرد لخدمـة المجتمـع والتوجيـهـ الرياضـي السـليم و إكســابه الـوعي الرياضــي و

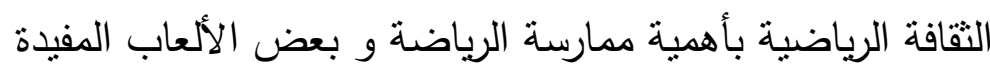
لذلك أدرك مخططو الإعلام في مصر الدور الرائد و الخلاق الذي يمكن أن يؤديه التليفزيون الإقليمي في مجال تتمية المجتمعات المحلية وتطورها مما ينصب إلى تحقيق أهداف التتمية القومية الثناملة و فتم إنثاء القنوات التليفزيون المحلية لتساهم في التعبير عن واقع البيئات المحلية المختلفة و شرح أمالها. ( ؟:A ) فوسائل الإعلام المحلية و خاصة قنوات التليفزيون تستطيع أن تعالج الخلل في التوازن الإعلامي داخل الدولة و الناتج عن تركز الإعلام في العاصمة فهي 
تشتطيع أن نطور نمطا اتصاليا جيدا يقوم على نطاق أفقي يمكن الجماهير من المشاركة الفعالة فى المجتمع فالتليفزيون المحلي يهتم برجع الصدى من الجمهور و

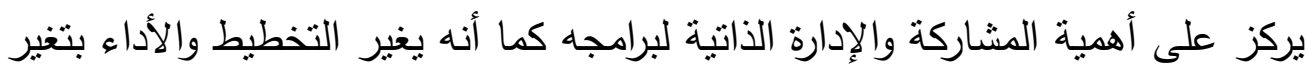

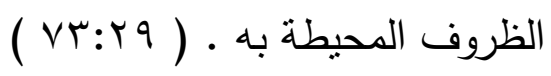

\section{و يتمثل دور القتوات التليفزيونية المحلية فى :-}

" تغطية كافة الأنشطة والإنجازات التي تدور في المجتمع المحلي . • تتمية الوعي النقافي ورفع المستوى الثقافي المحلي للمجتمع. • تتمية المهارات المختلفة ، وتغطية الأنشطة الرياضية والمسابقات المحلية والقومية . • التتمية الاجتماعية من خلال برامج رفيعة المستوى عن المجتمع والأسرة وكافة

$$
\text { قطاعات المجتمع }
$$

- المساهمة في تربية النشء تربية صحيحة والاكتشاف المبكر وللمهارات والمواهب

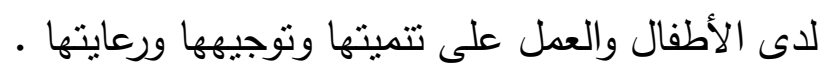
• خدمة الجمهور المحلي من خلال برامج خدمة البيئة والمساهمة في عرض وإيجاد الحلول لمشكلات المواطنين .

- التتمية الاقتصادية وعرض الأنشطة الاقتصادية بالمجتمع المحلي والعمل على رفع

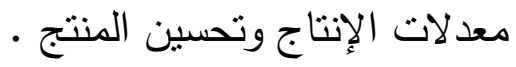

• الترفيه عن المواطنين وإسعادهم والترويح عنهم من عناء العمل ومشاكل الحياة

$$
\begin{aligned}
& \text { (IY):I) } \\
& \text { اليومية . }
\end{aligned}
$$

ممـا سـبق بتضــح لنـا أهميـة دور وسـائل الإعـلام الرياضـية بصـورة عامـة

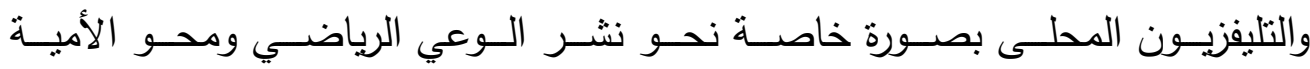
الرياضية و تدعيم القيم التربوية والاجتماعية . 
ويرى الباحثين أن البرامج الرياضية أصبحت بمثابة المدرسة العامة التي

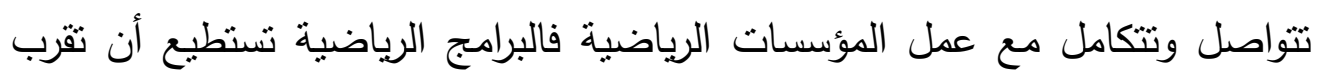
الفروق بين الأفراد عن طريق نشر الخبرات الايجابية وتعديل السلوك بين الصغار و الكبار بما يتلاءم والعادات والتقاليد الرياضية السليمة ونشر الفكر بأهمية دور الرياضة

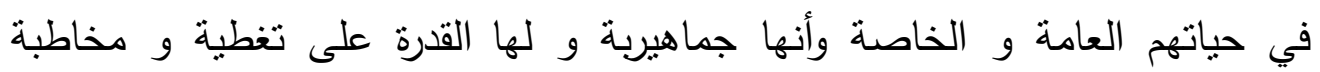
قطاعات كثيرة من الجماهيرو تهنم بكل القطاعات حتى الصغيرة العدد كالبرامج الرياضية للمعاقين وهكذا تكون مرآة وصورة للمجتمع وبهذا تشتجيب إلى البيئة التي تعمل فيها ، فهى بذلك لا تتعارض مع القيم والعادات و التقاليد السائدة في هذا لئه المجتمع.

فمن خلا عمل أحد الباحثين كمخرج للبرامج الرياضية بقناة طيبة واتصاله بالعاملين بالبرامج الرياضية من خلال مشاركتهم فى العمل والصعوبات التي تقابلهم

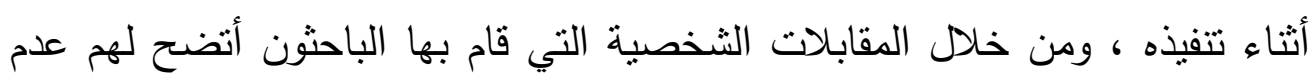
معرفة العاملين بالبرامج الرياضية بالدور الذي تقوم بـ تلك البرامج تجاه الجمهور

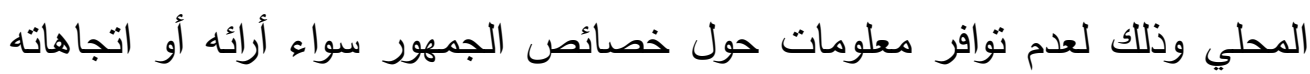

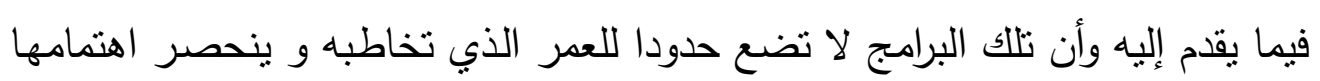
غالبا على الرياضـة الجماهيرية و تتجاهل الرياضات الأخرى. وهو ما دفع الباحثين لتتاول تلك الدراسة لمعرفة أراء العاملين تجاه البرامج الرياضية بالقناة الثامنة ومن ثم ثقويمها حيث أن القدرة على معرفة ذلك يؤثز ايجابيا فى تفعيل دور القنوات المحلية لخلق أجيال على درجة عالية من التقافة والوعي لهني الرياضي فتلك المعرفة تمكن القائمين بالعمل على معرفة ومدى مطابقة ما تم انجازه من أعمال طبقا لما كان مخطط له وإتمام تتفيذه من خلا التخطيط المسبق لذلك وأيضا دراسة الآثار التي تتتج عن تدخل بعض العوامل والظروف التى ساهمت فى من في النجاح أو فى الفشل بالنسبة للأهداف بغرض اكتثاف نقاط القوه ودعمها واكتشاف 
نقاط الضعف والقضاء عليها لتحقيق أقصى مدى لنجاح الأهداف الموضوعة وتحقيق مستوى عالى من الأداء

\section{أهميه البحث والحاجة إليه}

ا- في ضـوءو مـا اطلـع عليـة البـاحثين مـن أبحساث ودراسـات سـابقة أتضـح لـهـ

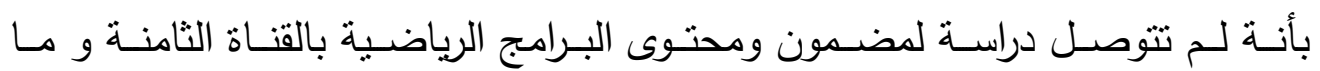

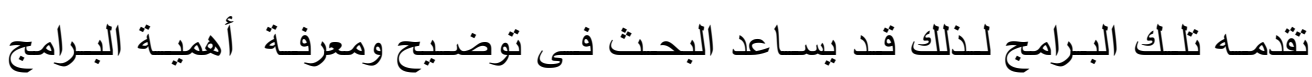
الرياضية تجاه الجمهور في جنوب الصعيد

r- المسـاهمة فـى تـوافر معلومـات وثنقــة حـول محتـوى ومضـمون مـا يقدم مـن

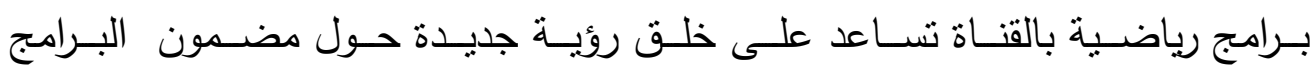
- الرياضية

ب- محاولــة الاســفادة مـن المقترحـات التـي يقـدمها العــاملين لتطــوير البـرامج

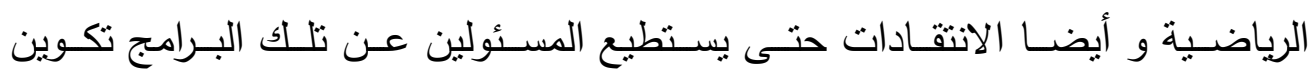
رأى يساعدهم عند الإعداد و التنفيذ لبرامج جديدة والتخطيط لها ـ لهابـ

\section{هدف البحث}

يهـدف البحــث إلـى تحسـين أداء العـاملين بـالبرامج الرياضـية بالقنـاة الثامنـة

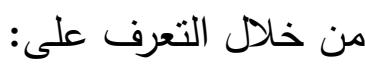

ا - رأى العاملين بالبرامج الرياضية فى الواقع الفعلى للبرامج الرياضية بالقناة الثامنة. r- وضع تصور مقترح لتحسين أداء البرامج الرياضية فى القناة الثامنة.

\section{تساوَلات البحث}

ا-ما رأى العاملين بالبرامج الرياضية فى الواقع الفعلى للبرامج الرياضية بالقناة

الثامنة؟ 
ץ-ما التصور المقترح لتحسين أداء البرامج الرياضية فى القناة الثامنة؟

المصطلحسات

القناة الثامنة:-

وهـو مـا يطلـق على التليفزيـون المحلـي لجنـوب الصـعيد و التـي يغطي

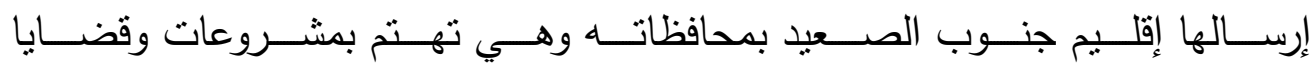

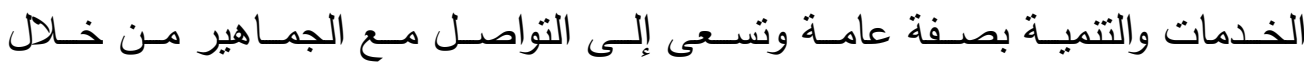

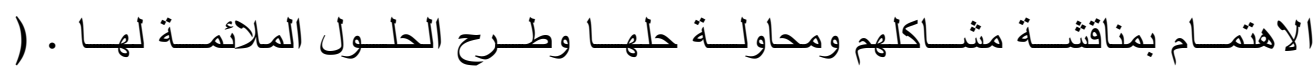

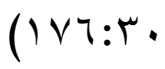

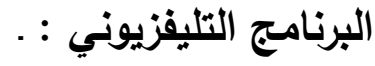

هو مجموعـة مـن الأنشطة والإجراءات ينت تتفيذها في توقيتات محددة في علاقة مخططة باستخدام موارد وتقنيات يتولى مسئوليتها أفراد يعطون على شكل فريق - نحقية الق داف تحداف لحت أهـ

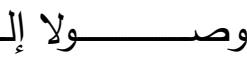
$(\varepsilon: v)$

يعتبر الإعلام منهج وعملية يقوم على هدف التتوير و الإحاطة بالمعلومات

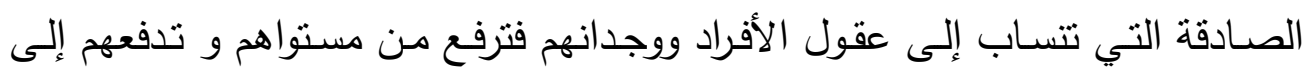
العمل من أجل المصلحة العامة و تخلق فيما بينهم مناخا يقظا يمكنهم من الانسجام و الحركة البسيطة و من ثم فإن الإعلام على هذا النحو يعد عملية ووظيفة اجتماعية تهدف إلى تتوير الرأي العام و معنى ذلك أن الأعلام ينطوي على عنصر التوجيـ الإنه بهدف أسمى هو تحقيق صـالح الأمة وما يجلب لها من رفاهيـة ولكى يكون الإعلام مؤثرا لابد لـه من عمليـة تقويم مستمرة تؤكد على ايجابيته وتعمل الحد من سلبياته

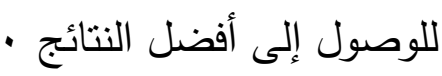




\section{1- تعريف الإتصال :}

ويمكن تعريف الإتصال بأنه عملية نقل الأفكار والآراء من شخص لأخر أو داخل نفس الفرد بغرض خلق الفهم لاي الثخص الموجه إليه الإتصال مما يؤدي إلي تغيير في

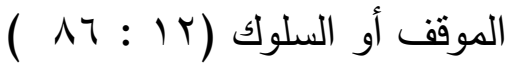

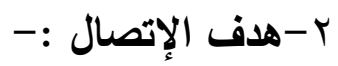

هو إحداث الفهم أو إدراك الآخرين للأمور من آجل أن يتحقق تغيير ما في وجهة نظرهم أو في سلوكهم نحو الأشياء والأشخاص والأفكار • ( 17 (1) وهى من أهم أنواع الاتصال في المجتمع هو ما يطلق عليه الاتصال المحلي

\section{r-الإتصال المحلي :}

والإتصـال المحلـى مـدخل أو تكنيـلك لا يقتصـر على أشـكال محـددة مـن وسـائل الإتصــال ، أو أنمـاط معينــة مـن الإتصــال ، ولكنــة يثـير إلـى اســتخدام

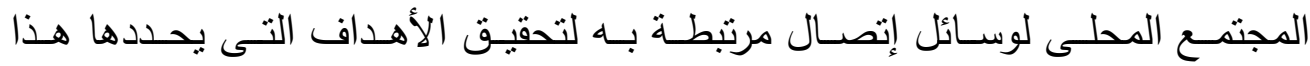

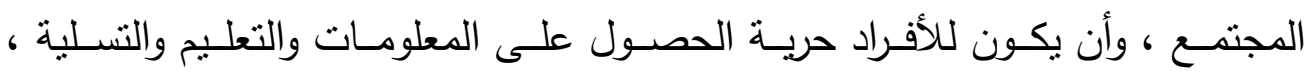

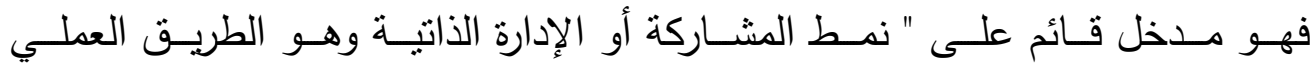
لتطبيـق ديمقراطيـة الإتصـال " التـي أوضـح احـد البـاحثين أنهـا تقوم على ثـلاث

$$
\text { ركائز هي :- }
$$

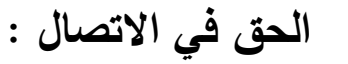

وهو يستتد إلى الحق الطبيعي للفرد في إن يجتمع مع الآخرين ، وان يعبر عن نفسه وان يعرف بصرف النظر عن المصدر ، الذي نأتى منه هذه المعرفة ، بالإضافة إلى حقه في الرد على المعلومات التي أستتد عليها فرد أو مجتمع بعينة . 


\section{الانتفاع :}

وهو يعنى إتاحة الوسائل للأفراد والمجتمعات وفرص الانتفاع بها لكي تتواصل فيما

$$
\begin{aligned}
& \text { بينهما ومع الآخرين . } \\
& \text { المشاركة : }
\end{aligned}
$$

وهـى تقـوم على أسـاس أن عمـل الوسـائل ينطلـق مـن افتـراض وجـود

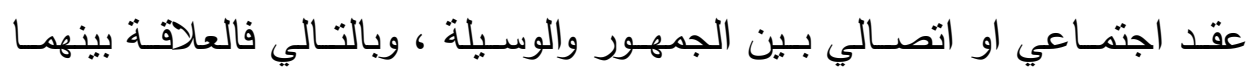

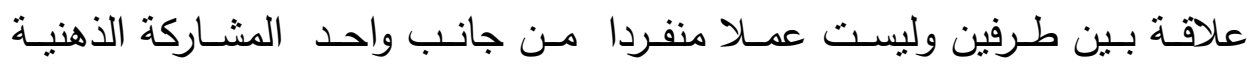

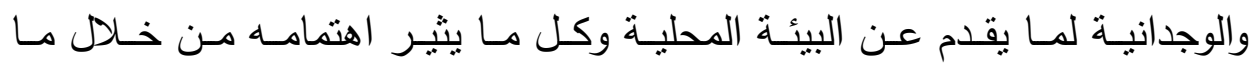

$$
\begin{aligned}
& \text { يقدم من قضايا محلية تهمه أو أراء المسئولين • (V) : V V (VT) } \\
& \text { ـ - دور الاتصال المحلي في تنمية المجتمع المحلي : }
\end{aligned}
$$

ثمقيـق " وحـدة المجتهـع المحلى Community Consensus " مـن خـلال التعرض لنفس المعلومات ، ونفس التفسير للأحداث ، مما يؤدى إلى تفكير الأفراد

$$
\text { بنفس الطريقة ، وليس المهم الوصول إلى نفس النتائج • }
$$

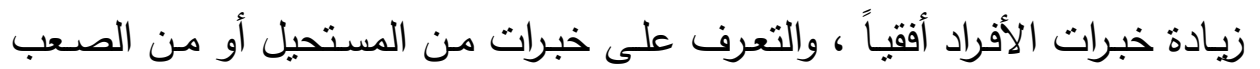

مشاهدتها بطريقة شخصية . ماهن

تسهيل حياه الفرد ، عن طريق تزويد الأفراد بالمعلومات عن الموضوعات الهامة

$$
\text { وطرح ومناقتة البدائل . }
$$

خلق الرغبـة في لرفاهيـة ، عن طريـق وصف طريقـة معيشية الآخربن ، وخلق

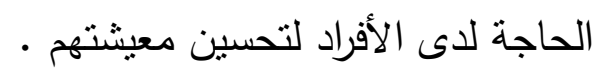

عرض الأفكار الجديدة في المجتمع المحلى ، وحث عملية المناقتشة حولها ، ونقل

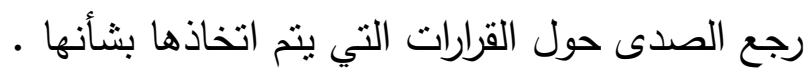

تعريف جمهور المجتمع المحلى بالخدمات والفرص المتاحة .

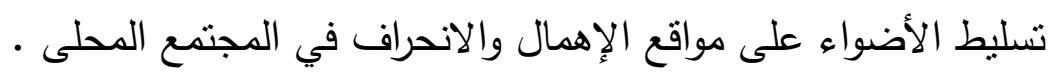


تقديم البرامج التى تسـاهم في التقيف البيئي والتتميـة الفكريـة والتقافي لجمهور

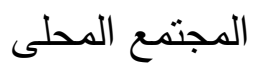

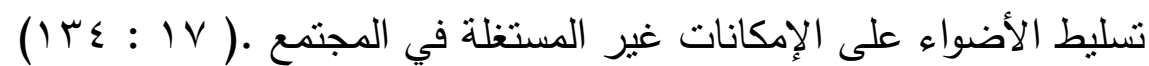

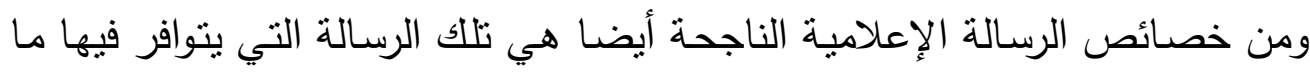

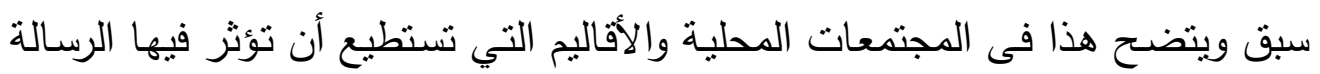
للتقارب في الصفات والطبائع والعادات والتقاليد فى تلك المجتمعات وهو مـا يتوفر بمجتمع البحث فى هذه الدراسة بإقليم جنوب الصعيد . لذا نستطيع أن نوضح الإعلام المحلى فيما يلي:

$$
\text { - مفهوم الإعلام المحلي : - مل }
$$

وهو الإعـلام الذي يخدم مجتمعـا محدداً ومتتاسـا مـن النـاحتين الاجتماعيـة $\ddot{a}$ والطبيع

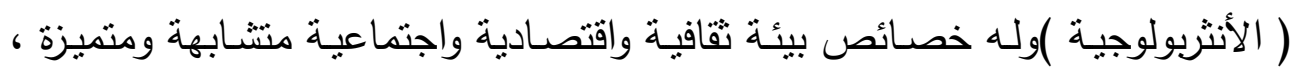
تجمع بين أفراده وحدة فكرية وثقافية وتراثهم وأفكارهم بل و لهجتهم المحلية وهو الإعلام

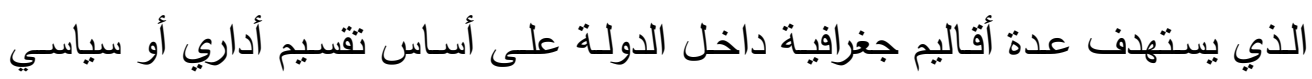
بصرف النظر عن التجانس البيئي بين هذه الأقاليم ، وينطبق هذا المفهوم على الإعلام

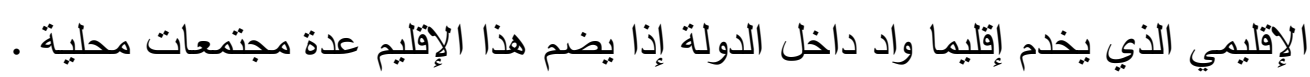

فإن الإعلام المحلي بصفة خاصة بعد مرآة لبيئة المواطن في المجتمعات المحلية نعكس صورة هو جزء منها فهو يعني على أن يكون الفرد ليس فقط مستفيدا

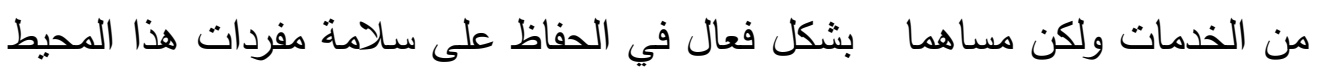

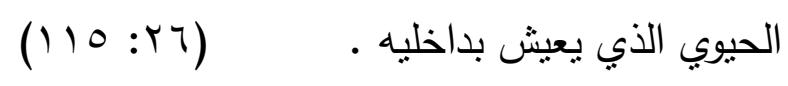




\section{- أهمية الإعلام المحلي :}

العمل على خلق مشـاركة أبنـاء المجتمـع المحلى في عمليـة التتميـة ، من خـلال تطوير إتصالي على نطاق مع تتمية رغبتهم حول أهمية تغيير مجتمعهم •

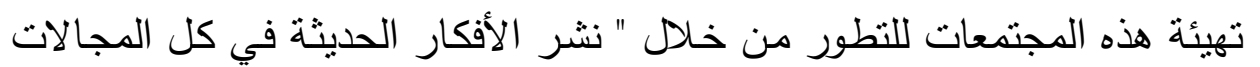
وحث الأفراد على تبنى هذه الأفكار والأساليب الحديثة " .

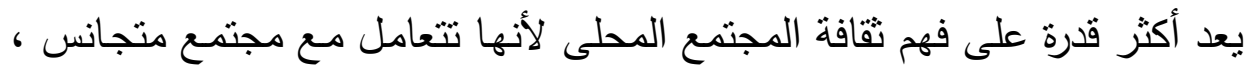

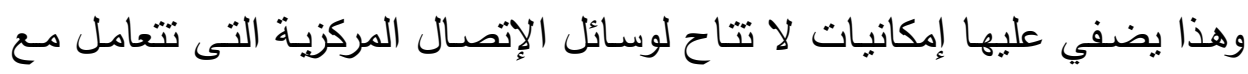
مجتمع كبير نسبياً وغير متجانس "

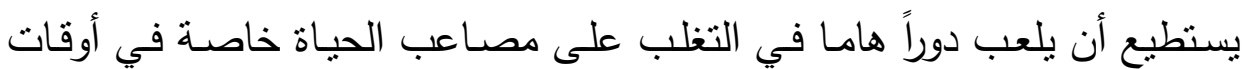

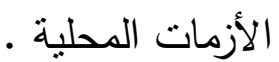

•• معالجة الخلل في التوازن الإتصالي ، الناتج عن تركز الإتصال في العاصمة. محاولة القضاء على القيم البالية والغربية عن المجتمع والمحافظة على قيمة الأصيلة ، وتأكيد القيم والمفاهيم الحديثة الإيجابية ، التى يمكن معها إعداد المواطن

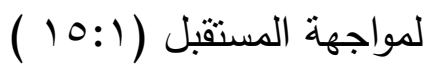
ويوجد في مصر الآن ستة قنوات تلفزبونية محلية عامـة القنوات الست هيى قناة القاهرة التى بدأت إرسالها في السادس من أكتوبر عام 9 ام ، ويعطى إرسالها (القاهرة الكبرى )، قناة القنال التى تعطى إرسالها ( محافظات القناة )، وقناة الإسكندرية

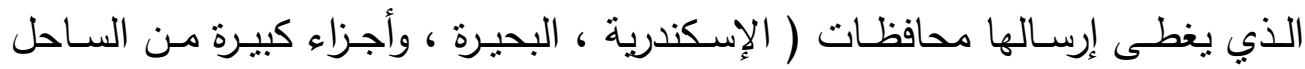
الثمالي ، والجهة الثمالية) ، وقناة الدلتا ويغطى إرسالها محافظات (الغربية ، الثرقية ، الدقهلية ، كفر الثيخ ودمياط) ، وقناة الصعيد التى يغطى إرسالها محافظات ( المنيا وبنـي سـويف وأسـيوط والفيوم) ، والقناة الثامنـة، والتـي يغطى إرسـالها محافظـات (

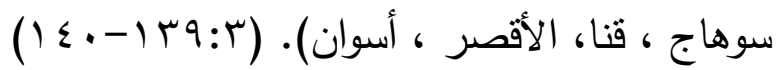


وتتبع أهمية هذه الخدمات المحلية من دورها في التتمية المحلية ، بما توفره من خدمة إعلاميـة متخصصــة ، تـدفع المـواطنين إلىى المسـاهمة الفعالـة والمشـاركة الإيجابيـة

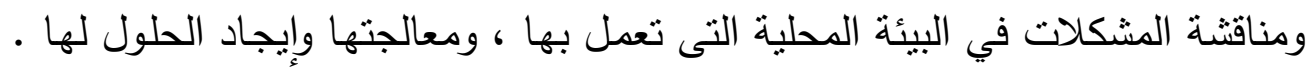
كما تسنطيع هذه القنوات المحلية القيام بدور فعال في تطوير سلوكيات المواطنين ، ورفع تطلعاتهم وطموحهم ، وتحسين مستوى معيشتهم ، عن طريق اقترابها الصـادق

منهم.

\section{- أهداف القنوات المحلية : -}

- تقديم المعلومات المتصلة بالمجتمع المحلي وإعلام فئات الجماهير في المجتمعات المحلية بالأحداث الجارية ومشروعات التتمية.

• عرض المشكلات والقضايا المحلية الحيوية ، ومناقتشها ، حيث يجمع خبراء الإعلام

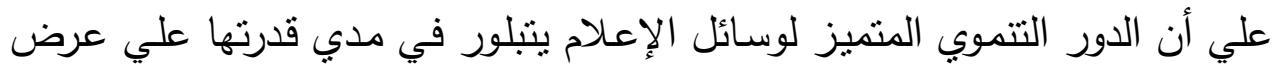
المشكلات التي يواجهها المجتمع بكفاعة والاستمرار في تكثيف المعالجة الإعلامية

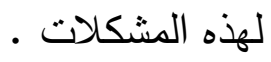
- السـعي وراء كثـف جوانـب الإهمـال والفسـاد في مواقـع العـلـ المختلفـة بـالمجتمع المحلي متى وجدت ، خاصة تلك التي تضر بمشروعات التتمية . • يؤدي التليفزيون الإقليمي دوراً متكاملاً مع وسائل الاتصال الاخري في التبشير بالقيم الجديدة المصـاحبة لمشـروعات التتميـة ، وتدعيم القيم التي تخدم التطور وتطوير أنماط السلوك الاجتماعية بما يتلاعم مع ظروف الحياة الجديدة المستهدفة . - توضيح الأساليب لاستغلال الإمكانات البيئية المتاحة لخدمة مشروعات التتمية . • الإعلام عن المشروعات الناجحة وإبراز الثخصيات ذات الأيادي البيضاء في إنجاح

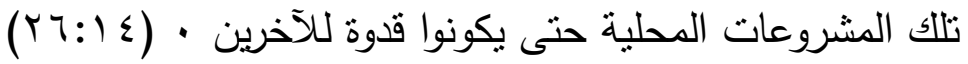
- التليفزيون: 
يعتبـر التلفيزيـون مـن وسـائل الاتصـال الجماهيريـة القويـة حيـث تغطى

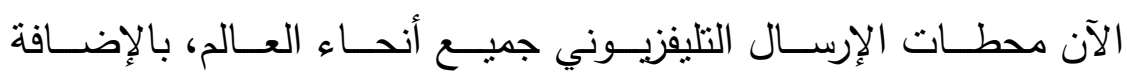

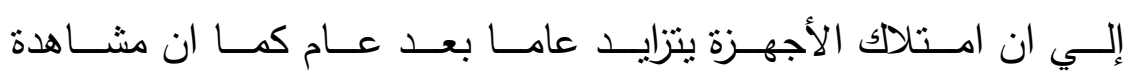
التليفزيــون لا تتطلـب مـن المشـاهد اى إسـتعدادات حيــث ان الرسـاله الإعلامية تذهب إلى المشاهد داخل منزله دون عناء. (10 : VT) - أساليب إنتاج البرامج التليفزيونية :تختلف أساليب إنتاج البرامج الإذاعية والتليفزيونية باختلاف الوسيلة واختلاف البرنامج

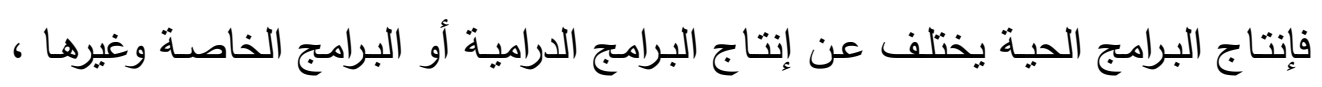

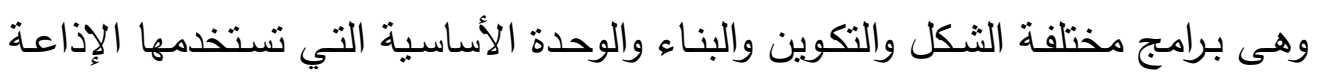
على سبيل المثنال الكلمـة والمؤثر الصـوتي والموسيقى وتستخدم الكلمـات في تكوين

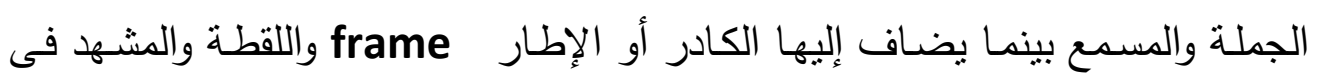
إنتاج البرامج التليفزيونيـة فالمشـاهد تتكون من لقطات مختلفـة متتاليـة وتعتبر اللقطـة

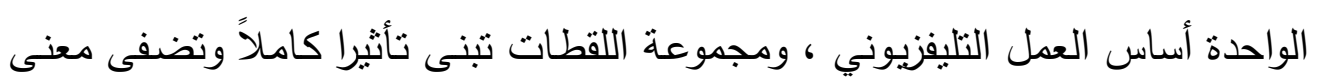

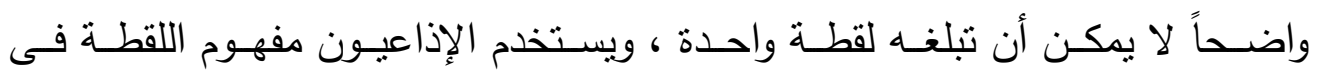
تسجيلاتها الصوتية تجاوزاً وتستمر اللقطة الواحدة بضع ثوان أو دقيقة وقد تكون طويلة تنتمر طبلة البرنامج اذا ما كان ذلك أفضل الأمور لعرض حادث يقع أمامنا ، ومن ثم

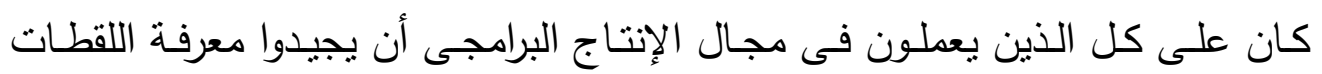

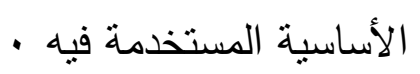

\section{- الإمكانات اللازمة للإنتاج البرامجى أو المرئي :-}

يتطلب الإنتاج البرامجى في محطات الإذاعة والتليفزيون توافر عدد من الإمكانات

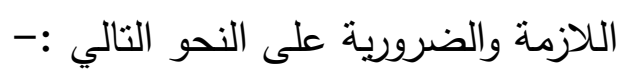

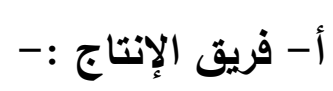


سواء من البرامجيين كالمعد أو كاتب النص والمخرج والمصورين والرسامين والخطاطين

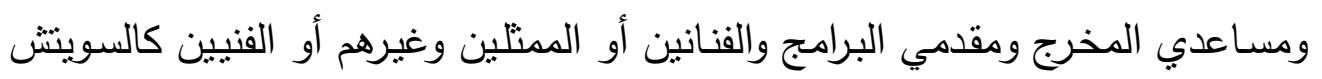
وفني الصـوت ومدير الاستديو وموزعي الإضـاءة ومسـجلي الصـوت والمسئولين عن الخـدمات الإنتاجيـة كالــديكور والإكسسـوار والملابـس والأثـاث والماكيـاج والمنــاظر • والمؤثرات وغيرهم

\section{ب- الأجهزة والمعدات الخاصة بنقل أو تسجيل الصوت والصورة :-}

كالكاميرات الخاصـة بالتصوير الاليكتروني أو الفيلمي والإضـاءة ومعدات الصوت من ميكروفونات وسماعات وأجهزة تكبير الصوت والنداء الالى والاتصال . . . . الخ الخ هذا بالإضـافة إلى الأفلام والثرائط الصـوتية على اختلافها ، والاسطوانات ، وشرائط

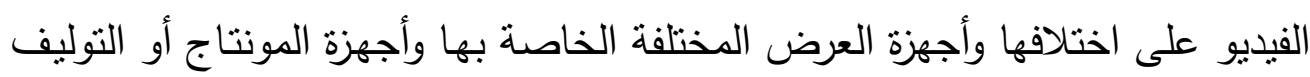
ووحدات النقل الخارجي ووصلات الميكروويف والهوائيات الخاصة بالتعامل مع الأقمار

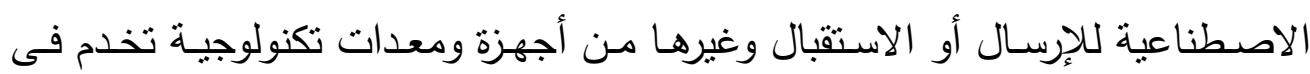
مجموعها عملية البث والاستقبال والتليفزيوني ، بالإضافة إلى المتطلبات الأخرى مثل الإنل الديكور والملابس أو الأزياء والماكياج ولوازمه والإكسسوار

ج- أماكن الإنتاج التليفزيوني ( استوديوهات الإذاعة والتليفزيون)

وهـى الأمـاكن الملائمسة والمخصصـة للإنتـاج البرامجى فـى الراديو والتليفزيـون والتـى

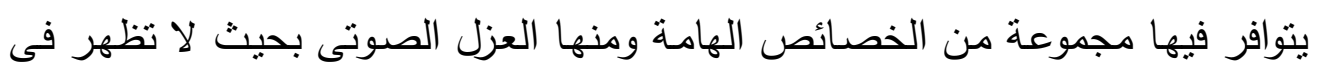

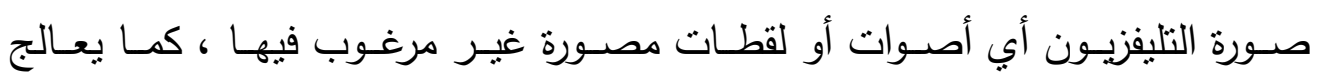

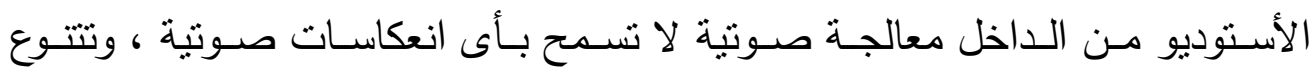
استوديوهات التليفزيون وفقاً لاستخدامها وحسب الأغراض المخصصة لها فى الإنتاج البرامجى ،فعلى سبيل المثال استوديوهات البـ والتتفيذ وهـى التى تستخدم فى بـث الرسائل التليفزيونية ، وتتفيذ البرنامج اليومى لها و استوديوهات التسجيل والإنتاج ومنها 
الإنتاج البرامجى اليومى كالأحاديث والندوات والمناقثـات والموسيقى والغناء ، وهنالك • استوديوهات الإنتاج الدرامي ( التمثيليات والمسلسلات ) د - الإمكانات المادية :-

يتطلب إنتاج البرامج التليفزيونيـة ميزانيـة ماليـة تختلف من خدمـة إلى أخرى ، ومـن برنـامج إلى أخر ، فبجانب الرواتب والأجور الثابتة ، يحتاج إنتاج البرامج الأمسوال

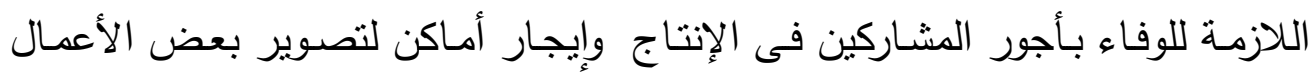

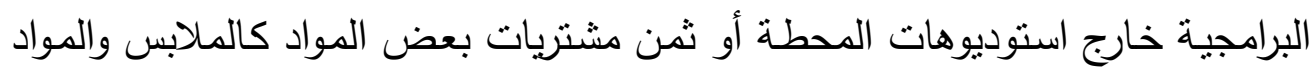

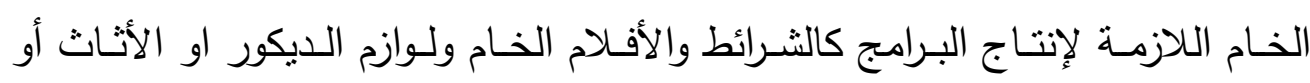
المناظر . . . إخخ وكل ذلك من متطلبات تقتضى إنفاقات مالية . و- الإلمام بطبيعة عملية الإنتاج وتنفيذها :بعد تحديد فكرة البرنامج ، والتعرف على جمهوره المستهدف من المشاهدين وتحديد أهداف البرنامج وشكله ومضمونه تتم كتابة نصه الذي يختلف من وسيلة لأخرى ، ومن برنامج لأخر وهى نماذج مختلفة التكوين والبناء فالبرامج الإخبارية تختلف عن البرامج الدرامية التى تختلف بالطبع عن البرامج المنوعة ، الأمر الذي يتطلب من الإسباء

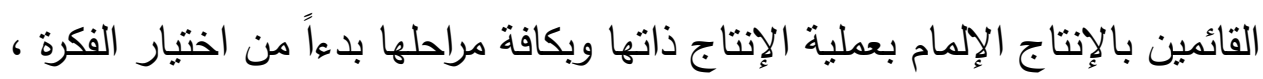

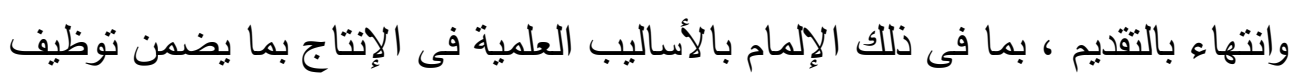

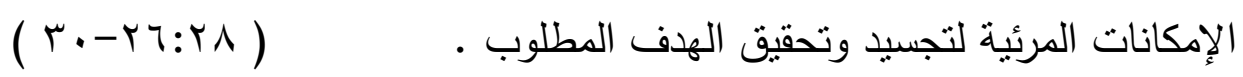

وجدير بالذكر أن البرامج الرياضية بالقناة الثامنة تختلف فى أفكارها ومضامينها وأهدافها فمنها ما يستهدف قطاع البطولة منل برنامج اللعبة الحلوة والأخر قطاع المدارس ومراكز الثباب مثل برنامج موعد مع الرياضة وأخر ينتاول أحداث

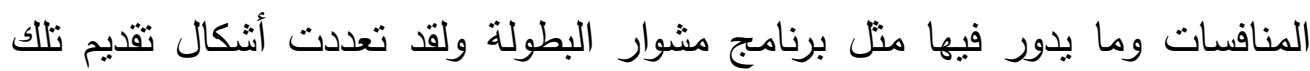

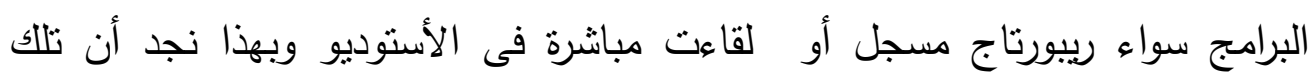


الأشكال والمضامين تتوعت لتخاطب الجمهور بكافة أثنكاله بهدف إكسابه المعلومات والمعارف الرياضية و تقديم الترويح في إطار من التسلية الممتعة والمفيدة .

\section{ثانيا : بعض الدراسات المرتبطة :--}

\section{أ- الدراسات العربية:-- 20 - n}

1- دراسـة أثـــرف منيـر صـبري (999 199) (7) بعنـوان " بنـاء اسـتراتيجية للبـرامج الرياضـية بـالتليفزيون المصـري " واسـتهدفت الدراسـة تحليـل طبيعـة البـرامج الرياضـية بـالتليفزيون المصـري ومعرفـة اتجاهـات الجمهور المصـري نحو البـرامج الرياضـية . واستخدم الباحثين الاستبيان كوسيلة لجمع البيانات وتم جمع البيانات من عينه عشوائية من الجمهور من سكان أقاليم القاهرة الكبرى الذي يضم محافظات ( القاهرة ـ الجيزة . القليوبية) عن طريق الاستبيان ، دراسة الحالة ، المقابلة الثخصية وأثـارت أهم النتائج إلي أن البرامج الرياضية بـالتليفزيون تتعامل مـع مفهوم الرياضـة مـن خـلال التصـور

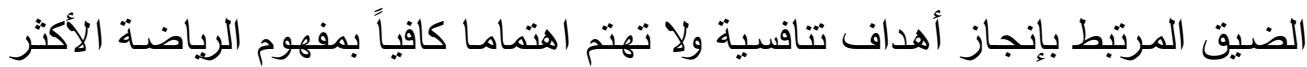
ثراءً علي الجانب الاجتماعي والثقافي والبرامج الرياضية من أكثر البرامج التي يفضل الجمهور مشاهدتها علي شاشة التليفزيون

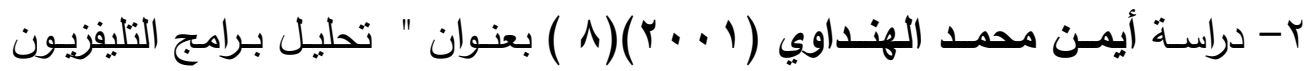
الرياضية وآثارها علي نشر الوعي الرياضي" واستهدفت الدراسـة التعرف علي البرامج الرياضية بالتليفزيون المصرى ودورها فى تتمية الوعى الرياضى وأسلوب تقديم البرامج الرياضية وعلاقته بجذب الجمهور واستخدم الباحثين الاستبيان كوسيلة لجمع البيانات

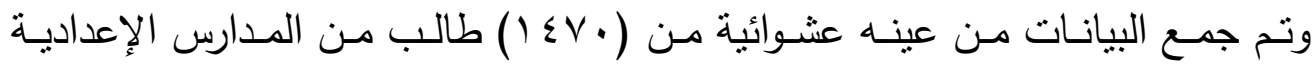
بمحافظـة الغربيـةو ( . . ()مـن خبـراء الاعـلام والرياضـة وأثـارت أهم النتائج البـرامج الرياضية بـالتليفزيون المصرى لاتتفق مـع ميول ورغبـات أفراد العينة ومبلهم لمشـاهدة

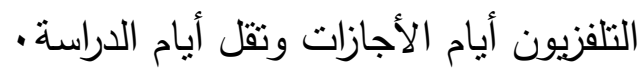




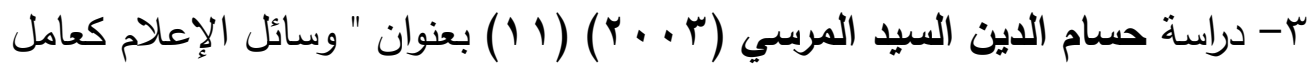
مـن العوامـل المؤثرة علـي اكتسـاب السـوك الرياضـي للجمـاهير " واستهدفت الدراســة

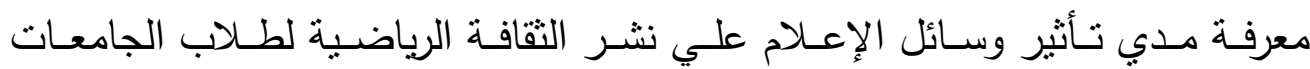

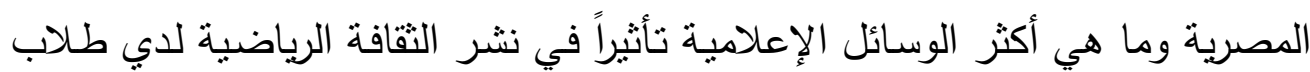
وطالبات الجامعات المصرية وأستخدم الباحثين المنهج الوصفي ( الدراسات المسحية )

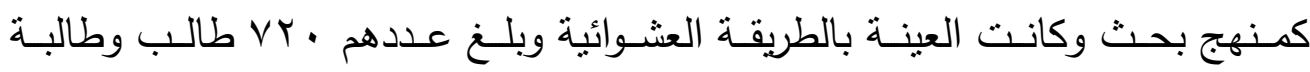
واسـتخدم المقابلـة الثخصـية واسـتمارة الاستبيان كوسيلة لجمـع البيانـات وكانـت أهـ النتائج تثير إلي أن البرامج الرياضية تهتم بنقل الأحداث الرياضية المختلفة بينما تهمل تقديم بـرامج تقدم للمشـاهد معلومـات قـد يسـتفيد منهـا في حياتـه اليوميـة ـ ويعتبر التليفزيون أهم وسيلة إعلامية نؤثر في نشر الثقافة الرياضية يليها الصحافة .

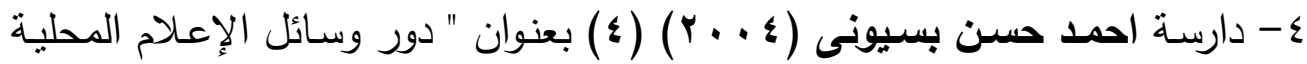
في تكوين المعرفة الرياضية لدى طلاب جامعة المنيا " واستهدفت الدارسة التعرف على دور وسـائل الإعـلام المحلية في تكوين المعرفـة الرياضية لدى طـلاب جامعة المنيا واستخدم البـاحثين المـنهج الوصفي وكـان الاستبيان كوسيلة لجمـع البيانـات وقد قـام الباحثين باختيـار عينـة البحث بـالطريق العشوائية وقوامها ( . . 0) طالب وطالبـة مـن طلاب جامعـة المنيا وكانت أهم النتائج نتشير إلى أن التليفزيون يلعب دورا كبيرا في تكوين المعرفة الرياضية لدى طلاب جامعة المنيا ثم الصحافة وهنالك قصور بالنسبة للإذاعة والوسائل الإعلامية الأخرى بالإضافة إلى تفاوت تأثثير كل وسيلة إعلامية في الجانب الرباضي تبعا لخصائص كلا منها

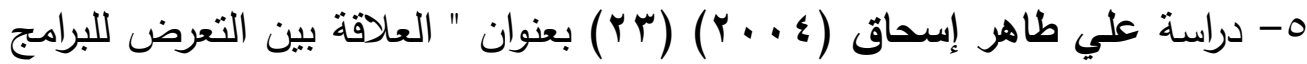
الرياضية بالراديو والتليفزيون والمعرفة الرياضية للجمهور المصري " واستهدفت الدراسة التعرف على ما هو معدل وانتظام الجمهور في التعرض للبرامج الرياضية وأسباب ونوع الاستفادة من ذلك واستخدم الباحثين المنهج الوصفي وكان الاستبيان كوسيلة لجمع 
البيانات وكانت نتيجة البحث نسبة المشاهدين للبرامج الرياضية في التليفزيون بلغ

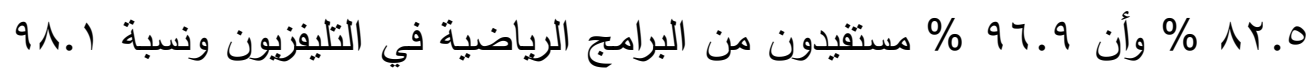
\% تزداد معارفهم الرياضية من متابعة هذه البرامج.

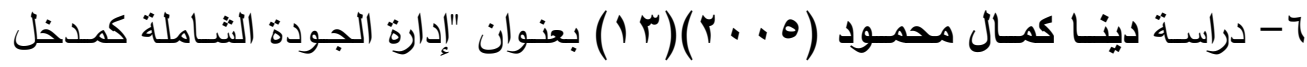
لتطوير البرامج الرياضية بالتلفزيون المصرى" واستهدفت الدراسـة التعرف على الجودة الثاملة كمدخل لتطوير البرامج الرياضية بالتلفزيون المصرى من خلال دراسة الوضع الراهن لإدارة البرامج الرياضية بقتـاة النيل للرياضـة وتحليل طبيعـة البرامج الرياضية ودراسـة إدارة الجودة الثـاملة ودورهـا فى تطوير البرامج الرياضية واستخدم البـاحثين

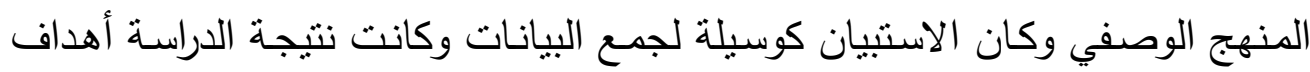
قناة النيل للرياضـة غير واضحة و أهداف الجودة الثـاملة تسـاهم فى تطوير البرامج الرياضية بقناة النيل للرياضة ولا توجد لجنة تخطيط للبرامج والتدريب المؤهل للعاملين غير موجود -

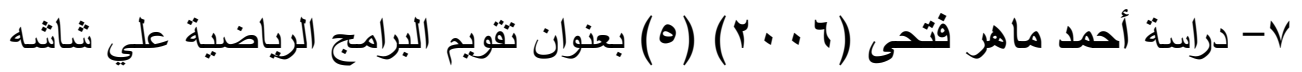
القناة السادسة بتلبفزيون وسط الدلتا واستهدفت الدراسة تقويم البرامج الرياضية بالقناة السادسة بتليفزيون وسط الدلتا استخدم الباحث المنهج الوصفي من الدراسات المسحية لمناسبته لطبيعة هذه الدراسه وقد تم اختيار عينه البحث بالطريقة العمديه العشوائية من مشاهدي البرامج الرياضية بالقناة السادسة من جمهور محافظه الغربية وبلغ حجم العينة

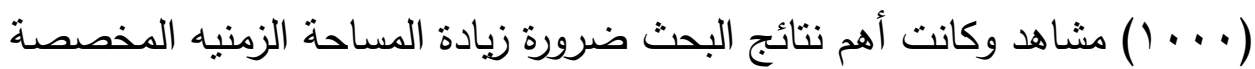
للبرامج الرياضية بالقناة السادسة بتليفزيون وسط الدلتا الاهتمام بزيادة عدد البرامج الرياضية وإضافة برامج خاصة بذوي الاحتياجات والتتوع في الفقرات والمواد الحية ضرورة إعادة تأهيل وتدريب القائمين علي البرامج الرياضية بالقناة السادسة حتي يلحقوا بركب التقدم للمرحلة الاعلاميه القادمة . 


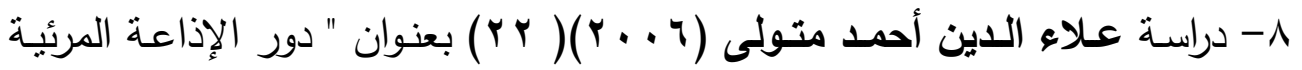
المحلية فى تتمية الوعى الرياضى فى نشاط السباحة لتطوير مجال السياحة و العلاج و الترويح " واستهدفت الدراسة مدى مساهمة البرامج الرياضية بالإذاعة المرئية المحلية فى الارتقاء بالمستوى الفكرى لدى جمهور المشـاهدين و العمل على إقبال الجمهور على مشـاهدة البرامج الرياضية الخاصـة بنشاط السباحة لمـا لها من فوائد عديدة فى لـى مجـال السياحة و العـلاج و الترويح و ذللك مـن خـله دراسـة دور الإذاعـة المرئيـة المحلية فى تتمية الوعى الرياضى لنشاط السباحة و لتطوير مجال السباحة السياحية ونية الداخليـة و السـباحة العلاجيـة ونشـاط السـياحة الترويحيـة اسـتخدم البـاحثين المـنهج الوصفي واختار الباحثين العينة بالطريقة العشوائية وتكونت حجم العينة من ( • ع) خبيراً ، و (79 § ) مشاهداً من محافظة الإسكندرية و كانت أهم النتائج التى توصل إليها أنه لايوجد فى الوقت الحالى (وقت تتفيذ البحث) دور الإذاعة المرئية المحلية فى تتمية

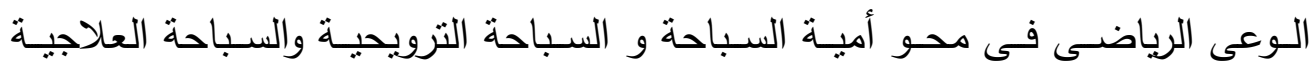
والسباحة الرياضية الداخلية و الميل الرياضى و لايوجد دور للإذاعة المرئية المحلية

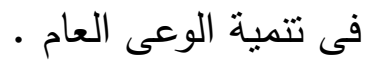

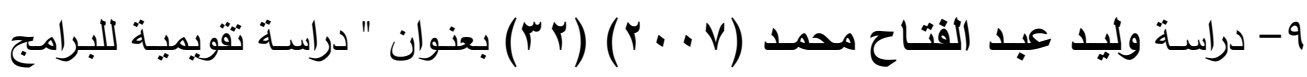
الرياضـية بالقنـاة الثانيـة بـالتليفزيون المصـري " واسـتهدفت الدراسـة تقويم للبـرامج الرياضية بالقناة الثانية بالتليفزيون المصري واستخدم الباحث المنهج الوصفي وكانت عينة البحث من لاعبي الألعاب الجماعية و الفردية بالدوري الممتاز وكان حجم العينة

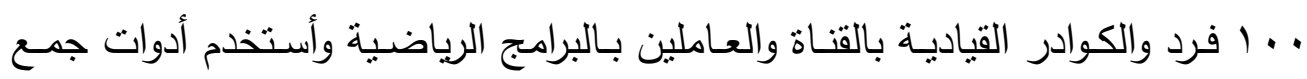

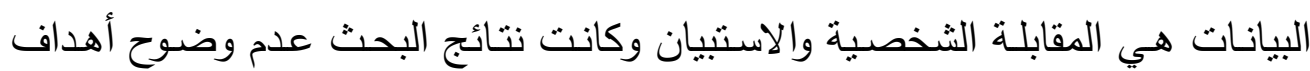
البرامج الرياضية بالقناة الثانيـة للعاملين وقصور التخطيط حيث بشـارك فيه القبادات

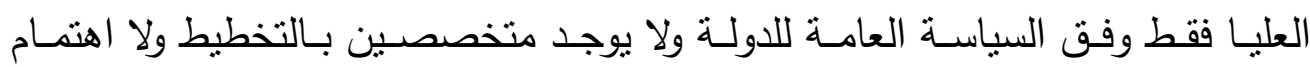
بالايكور المخصص للبرامج • 
• 1 - دراسة أيمن محمد الهنداوي ( • • ( ) 9 ( ) بعنوان "الإعداد المهنى والتوصيف الوظيفي لمعد البرامج الرياضية بـالتليفزيون المصـرى واستهدفت وضـع تصسور مقترح الإعـداد المهنـى والتوصـيف الـوظيفي لمعـد البـرامج الرياضـية بـالتليفزيون المصـرى وأستخدم الباحث أدوات جمع البيانات هي المقابلة الشخصية والاستبيان وكانت عينة البحث اشتملت على (م (1) خبير من خبراء الإدارة الرياضية و الإدارة العليا بإتحاد الإذاعة والتلفزيون والعاملين بالبرامج الرياضية بـالتلفزيون المصرى وكانت أهم نتائج

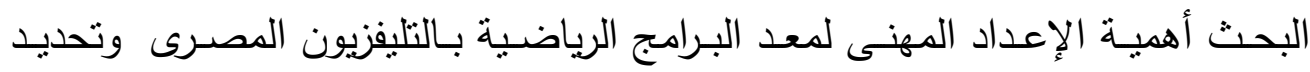

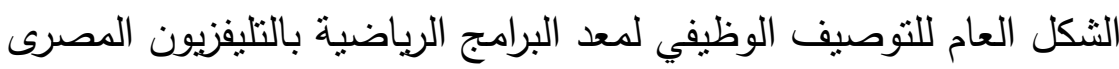
ب - الدراسات الأجنبية: --

Gender equity in sports (1994) Shifflet,-B;Revelle-R دراسة) media coverage الرياضية " واستهدفت الدراسة تحديد مدي التغطية الإعلامية للإناث والذكور و مقارنة مباشرة بين المساحة المخصصة للذكور والإناث الرياضيين والمدربين وأيضاً المخصصة لرياضتهم وأستخدم الباحث المنهج الوصفي وكانت أهم النتائج أن هنالك نقص في نسبة تمثيل الإناث بالنسبة للذكور .هناك اهتمام واضح بالتغطية الإعلامية

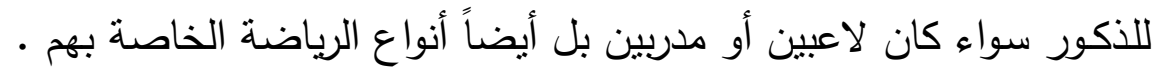

Public television and high (1995) Patrick Richard دراسـة بعerformance sport in canda بأداء الرياضة الكندية " استهدفت الدراسة توضيح مدي أهمية ارتباط الرياضة بوسائل الإعلام واستخدم الباحث المنهج الو صفى وكانت عينة الدراسة من جماهير مباريات

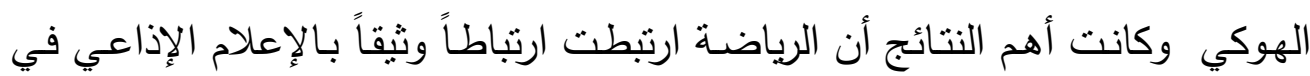

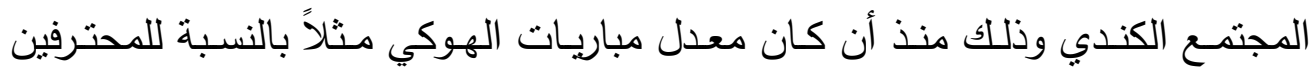
محدود للغايـة في العشرينات حيت وصلت هذه الصـناعة إلي ملايين الدولارات في بي 
التسعينات وان هيئة الإذاعة الكندية وكذلك شبكة التليفزيون المتحدث باللغة الإنجليزية كأول منتج للرياضة ذو المستوي الرفيع لا تعمل علي نشر التقافة الرياضية بين متابعي

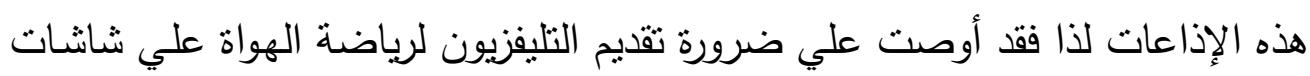

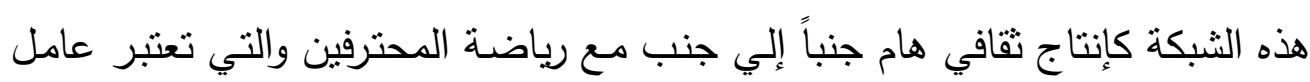
جذب لمتابعة هذه الإذاعات.

Influence of sport media on teenaged (1996) CHEN-T rاستة students sports participation

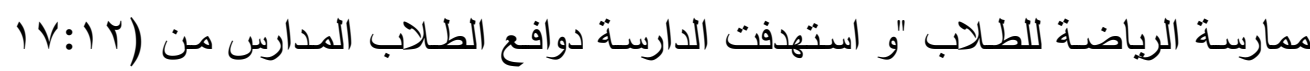
سنة ) للمشـاركة في فصـول التربيـة البدنيـة وممارسـة الرياضــة ومعرفـة مـا حققوه فيها تحليل تلك الدوافع والإنجازات وأستخدم الباحث المنهج الوصفي وكانت عينة الدراسة البها.

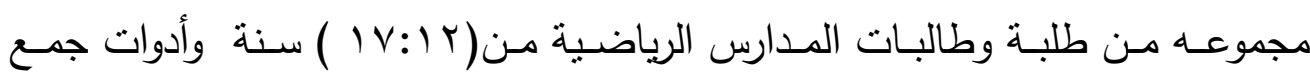

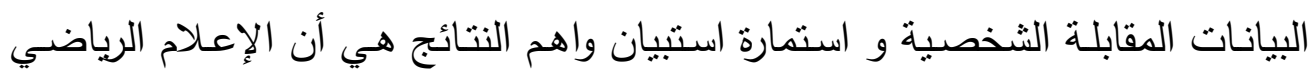

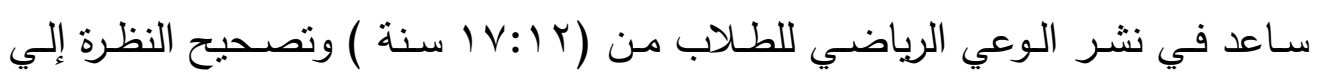
أهمية الرياضة وقيمتها.

Astudy of the Relationship (1998) SHIH-CHIH-PIN ع دراسـة-1 Between Media Coverage

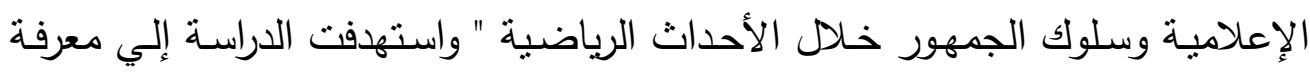

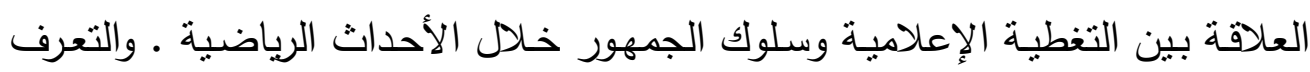
علي تأثثر التغطية الإعلامية علي الجمهور .وأستخدم الباحث المنهج الوصفي وكانت أدوات جمع البيانات المقابلة الثخصية ، استمارة استبيان وكانت العينـة من جمهور

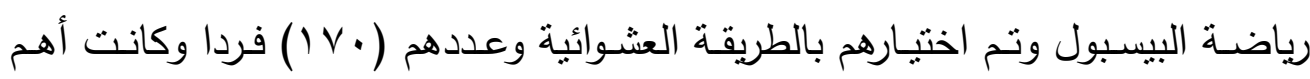
النتائج أن الطلاب والثباب الأقل من مب سنة هم أكثر الجمهور في حضور ولثة المباريات 
، وأن التغطيـة الإعلاميـة والتعريف بـالفريق والتشلية وقوة الجذب للجمهور لا تعتبر التوقع الإيجابي لله علاقة بارتباط الجمهور ولعبة البيسبول .

\section{ج- التعليق علي الاراسات المرتبطة:}

استطاع الباحثين حصر مجموعة من الدراسات السابقة العربية والأجنبية حيث

ألقت تلك الدراسات الضوء على الكثير من المعالم التي تقيد الدراسة الحالية ، فكان لها جهود بحثيـة قيمة لم يسبق للباحث التعرف عليها الأمر الذي قد أثنار للى الباحثين أفكار جديدة لمعالجـة موضـوع الدراسـة الحاليـة ، وخاصـة وان البرامج الرياضـية مـن

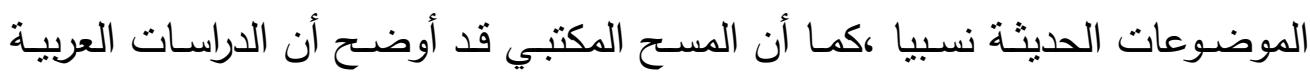
تفتقر إلى العديد من الدراسات والبحوث التي تتعرض إلى مشكلات البرامج الرياضية

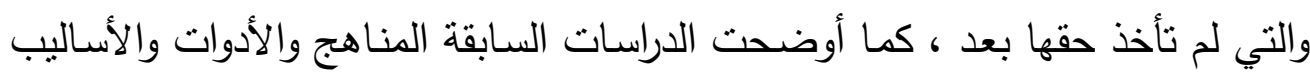

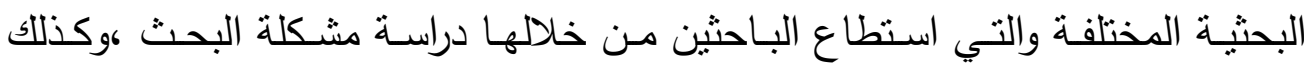
التوصل إلي نتائج البحث ،حيث سار الباحثين علي ما هو مفروض ومتبع من حيث ما انتهي إليه الآخرون فقد استعان الباحثين بنتائج الدراسات السابقة في تدعيم البحث من خلال:

مالتعرف علي أفضل الإجراءات المناسبة والتي يمكن أن تؤدي إلي تحقيق أهداف الدراسة .

متحديد المنهج العلمي المستخدم في الدراسة الحالية .

متحديد الأسلوب الإحصائي المناسب لطبيعة الدراسة -

مطريقة اختيار العينة التي تتناسب مع طبيعة الدراسة .

$$
\text { متحديد أدوات جمع البيانات . }
$$

موضع تساؤلات البحث في ضوء هدف الدراسة . 
مناقشة وتفسير نتائج الدراسة الحالية في ضوء ما توصلت اليه تلك الدراسات

- المرتبطة

خطة وإجراءات البحث

منهج البحث:

استخدم الباحثين المنهج الوصفي (المسح الميداني) لملاءمته وطبيعة وأهداف البحث.

\section{مجتمع وعينة البحث:}

يشمل مجتمع البحث العاملين بالبرامج الرياضية فى القناة الثامنة

وقد تم إجراء البحث على عينة بالطريقة العشوائية طبقاً لأهداف البحث تمثلت في

التالي:

- العاملين بالبرامج الرياضية بالقناة الثامنة وتم أاختيارهم بأسلوب الحصر الثامل

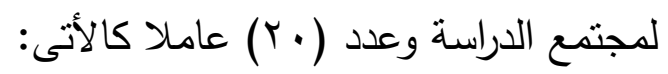

- عدد (7) معد برامج

- عدد (r) مصور تليفزيوني

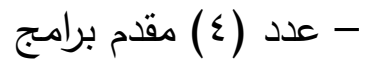

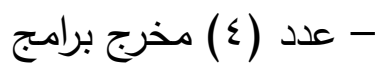

- (بد) - (r) مراسل

\section{-أدوات جمع البيانات:}

إستعان الباحثين بالاستبيان كأداة لجمع البيانات وقام بتصميم استمارة استبيان كالأتى :

- إستمارة استبيان للتعرف على رأي العاملين بالبرامج الرياضية الواقع الحالى البرامج الرياضية بالقناة الثامنة.

أولا : خطوات تصميم استمارة الاستبيان : 


\section{ا}

لكي يتمكن الباحثين من تحقيق هدف البحث في وضع خطة مقترحة للبرامج الرياضية وذللك بالتعرف على الواقع الحالي للبرامج الرياضية بالقناة الثامنة من خلص رأى العاملين بالبرامج الرياضية تجاه ما يقدمونة.

$$
\text { r- ت تحديا محاور الاستبيان : }
$$

بعد الاطلاع علي الدراسات السابقة قام الباحثين بتظيم المحاور الرئيسية في صورتها

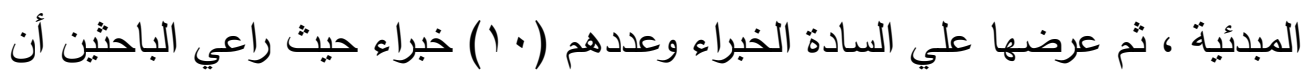

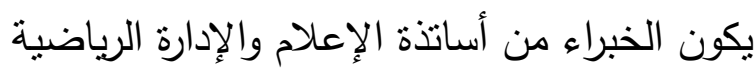

بعد ذلك قام الباحثين بعرض المحاور الرئيسية بصورتها المبئية في علي الخبراء بهدف الوصول إلي مدي مناسبة المحاور وكفايتها وذلك للتعرف علي : - مدي مناسبة وكفاية المحاور الرئيسية الخاصة بآراء الجمهور والعاملين للواقع الفعلي بالبرامج الرياضية بالقناة الثامنة . - تعديل أو حذف أو إضافة ما يراه الخبراء من محاور رئيسية وبعد عرض الاستمارات علي الخبراء قام الباحثين بحساب النسبة المئوية لآراء السادة الخبراء حول المحاور الرئيسية وفقا للجداول التالية :-

$$
\text { جدول ( ) (1) - (1) }
$$

النسبة المئوية لأراء الخبراء للمحاور الرئيسية الخاصة

$$
\text { جدول (1) - (1) - (1) }
$$

النسبة المئويـة لأراء الخبراء للمحساور الرئيسية الخاصة

باستبيان رأي العاملين بالبرامج الرياضية بالقتاة الثامنة

$$
(1 \cdot=0)
$$




\begin{tabular}{|c|c|c|c|c|}
\hline المئوية & مناسب & مناسب & المحاور الرئيسية & p \\
\hline$\% 1 \ldots$ & - & 1. & الأهداف العامة للبرامج الرياضية & 1 \\
\hline$\% 70$ & $\mathrm{~V}$ & $\mu$ & أهداف وسيلة الاتصال(التلفزيون) & r \\
\hline$\% 90$ & 1 & 9 & التخطيط للبرامج الرياضية & $\Gamma$ \\
\hline$\% 9$ & r & $\Lambda$ & التمويل في البرامج الرياضية & $\varepsilon$ \\
\hline$\%$ & - & 1. & ( الزمن - التوقيذ البرامج الرياضية ـ التنفيذ ) & 0 \\
\hline$\% 7$. & $\Lambda$ & r & تحليل البرامج الرياضية & 7 \\
\hline$\% 1 \ldots$ & - & 1. & (الإمكانات بالبرامج الرياضية & $V$ \\
\hline
\end{tabular}

يتضح من الجدول السابق ( 1 ) أن النسبة المئوية لآراء السادة الخبراء حول المحاور

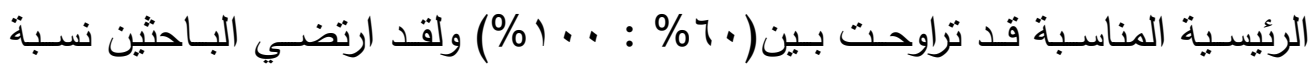
(\% فأكثر من آراء السادة الخبراء لتحديد أهم المحاور الرئيسية لاستمارة استطلاع رأي العاملين بالبرامج الرياضية حول البرامج الرياضية ويصبح الثكل النهائي للمحاور الرئيسية للاستبيان كالتالى:

1- الأهداف العامة للبرامج الرياضية r- التخطيط للبرامج الرياضية r- التمويل في البرامج الرياضية ع - تنفيذ البرامج الرياضية ( الزمن - التوقيث - التنفيذ ) 
0- الإمكانات بالبرامج الرياضية ( مادية- بشريةــ تقتية) r- إعداد عبارات الاستبيان :

فـي ضــوء نتــائج آراء الخبـراء حـــول المحــاور المقترحسـة قـام البــاحثين

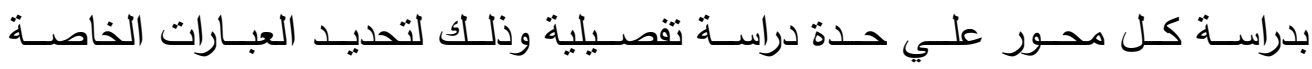
بكـل محسور رئيسـي وفرعي مسترشـدا بـبعض المراجـع العلميـة والدراسـات السـابقة

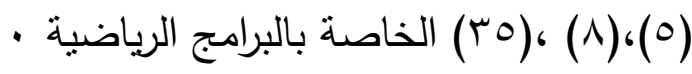
ثم قـام البـاحثين بصـياغة مجموعـة مـن العبـارات التـي يمكن أن نتـدرج تحـ كـل محـور وتــم إعـداد اســتمارات الاسـتبيان فـي صـــورتها المبدئيــة وتـم عـرض

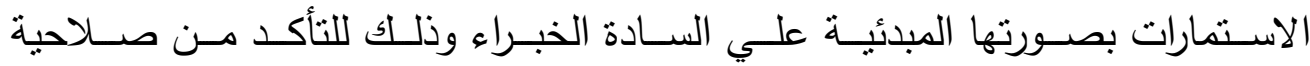
اسـتمارة الاسـتبيان كـأداة لجمـع البيانـات والتعـرف علـي مــدي مناسـبة العبـارات

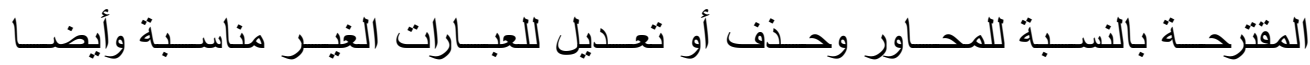
إضافة أية عبارات أخري مقترحة تكون غير مدرجة بالاستمارة والجداول

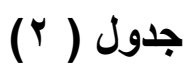

النسبة المئوية لأراء السادة الخبراء حول عبارات إستبيان
$(1 \cdot=\dot{0})$
(آراء العاملين تجاه البرامج الرياضية )

\begin{tabular}{|c|c|c|c|c|c|c|c|c|c|}
\hline \multicolumn{2}{|c|}{ المحور الخامس } & \multicolumn{2}{|c|}{ المحور الرابع } & \multicolumn{2}{|c|}{ المحور الثُالث } & \multicolumn{2}{|c|}{ المحور الثاني } & \multicolumn{2}{|c|}{ المحور الأول } \\
\hline \multicolumn{2}{|c|}{ الإمكانات لبرامجية } & \multicolumn{2}{|c|}{ تنفيذ البرامية } & \multicolumn{2}{|c|}{ للبرامج الرياضية فية } & \multicolumn{2}{|c|}{ تخطيط البرامج } & \multicolumn{2}{|c|}{ أهداف البرامية } \\
\hline النسبة & العبار & النسبة & أعبار & النسبة & العبار & النسبة & $\begin{array}{l}\text { العبار } \\
\text { الع }\end{array}$ & النسبة & العبار \\
\hline \% & 1 & 1\% & 1 & $\%$ \%. & 1 & \% & 1 & $\ddot{\%}$ & 1 \\
\hline
\end{tabular}




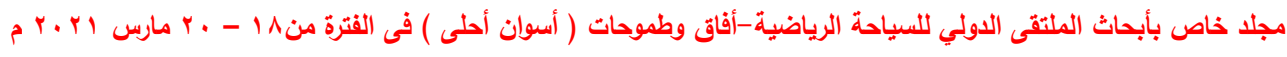
(العدد الثانى)

\begin{tabular}{|c|c|c|c|c|c|c|c|c|c|}
\hline $\begin{array}{l}1 \ldots \\
\%\end{array}$ & $r$ & $\% \wedge$. & $r$ & $\begin{array}{l}1 \ldots \\
\%\end{array}$ & r & $\% \wedge$. & $r$ & $\begin{array}{l}1 \ldots \\
\%\end{array}$ & $r$ \\
\hline$\% 7$. & $r$ & $\begin{array}{l}1 \ldots \\
\%\end{array}$ & $r$ & $\% 9$. & $r$ & $\begin{array}{l}1 \ldots \\
\%\end{array}$ & $r$ & $\begin{array}{l}1 \ldots \\
\%\end{array}$ & $\mu$ \\
\hline$\% 9$. & $\varepsilon$ & $\begin{array}{l}1 \ldots \\
\%\end{array}$ & $\varepsilon$ & $\begin{array}{l}1 \ldots \\
\%\end{array}$ & $\varepsilon$ & $\begin{array}{l}1 \ldots \\
\%\end{array}$ & $\varepsilon$ & $\%$ & $\varepsilon$ \\
\hline $\begin{array}{l}1 \ldots \\
\%\end{array}$ & 0 & $\% 7$. & 0 & $\begin{array}{l}1 \ldots \\
\%\end{array}$ & 0 & $\% 7$. & 0 & $\begin{array}{l}1 \ldots \\
\%\end{array}$ & 0 \\
\hline$\% 0^{\circ}$ & 7 & $\begin{array}{l}1 \cdots \\
\%\end{array}$ & 7 & $\% \wedge$. & 7 & $\begin{array}{l}1 \ldots \\
\%\end{array}$ & 7 & $\% 4$. & 7 \\
\hline $\begin{array}{l}1 \ldots \\
\%\end{array}$ & $V$ & $\begin{array}{l}1 \ldots \\
\%\end{array}$ & V & $\begin{array}{l}1 \ldots \\
\%\end{array}$ & V & $\% 9$. & V & $\% 9$. & V \\
\hline $\begin{array}{l}1 \ldots \\
\%\end{array}$ & $\Lambda$ & $\% 9$. & $\Lambda$ & $\% \vee$ & $\Lambda$ & $\% 0^{\circ}$ & $\Lambda$ & $\begin{array}{l}1 \ldots \\
\%\end{array}$ & $\Lambda$ \\
\hline$\% \wedge$. & 9 & $\begin{array}{l}1 \cdots \\
\%\end{array}$ & 9 & $\% 7$. & 9 & $\% 7$. & 9 & $\% \wedge$. & 9 \\
\hline $\begin{array}{l}1 \ldots \\
\%\end{array}$ & 1. & $\% 7$. & 1. & $\begin{array}{l}1 \ldots \\
\%\end{array}$ & 1. & $\% 0^{\circ}$ & 1. & $\% 7$. & 1. \\
\hline $\begin{array}{l}1 \ldots \\
\%\end{array}$ & 11 & $\%$ & 11 & $\begin{array}{l}1 \ldots \\
\%\end{array}$ & 11 & $\%$ & 11 & $\% 0^{\circ}$ & 11 \\
\hline$\% 9$. & Ir & $\begin{array}{l}1 \ldots \\
\%\end{array}$ & $1 r$ & & & $\begin{array}{l}1 \ldots \\
\%\end{array}$ & Ir & $\% 0^{\circ}$ & Ir \\
\hline$\%$ & ir & $\% \vee$. & 1r & & & $\% 9$. & Ir & $\% \wedge$ & $1 \%$ \\
\hline $\begin{array}{l}1 \ldots \\
\%\end{array}$ & $1 \varepsilon$ & $\% 9$. & $1 \varepsilon$ & & & $\% 9$. & $1 \varepsilon$ & $\begin{array}{l}1 \ldots \\
\%\end{array}$ & $1 \varepsilon$ \\
\hline$\% 7$. & 10 & $\begin{array}{l}1 \ldots \\
\%\end{array}$ & 10 & & & $\begin{array}{l}1 \ldots \\
\%\end{array}$ & 10 & $\begin{array}{l}1 \ldots \\
\%\end{array}$ & 10 \\
\hline$\% 9$. & 17 & $\% 9$. & 17 & & & $1 \ldots$ & 17 & $\% 7$. & 17 \\
\hline
\end{tabular}




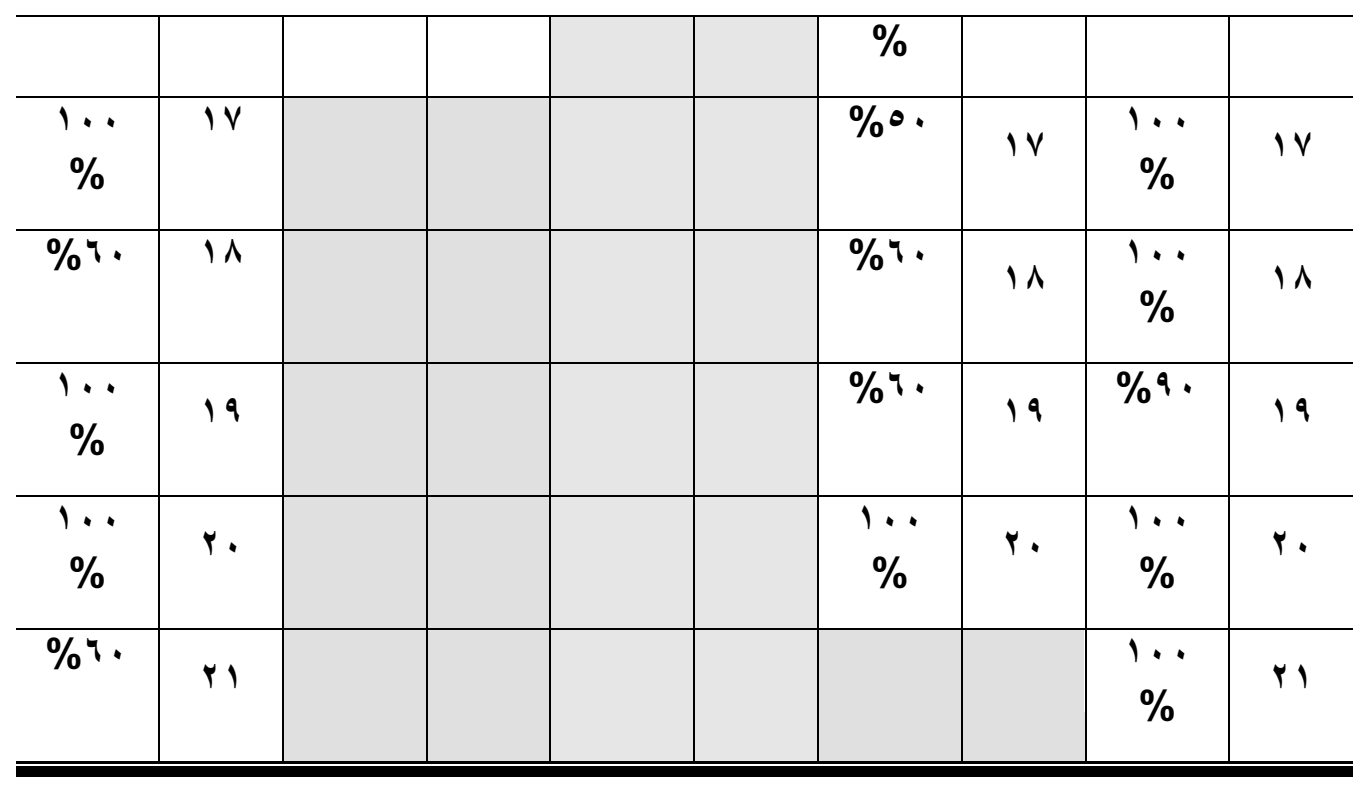

يتضح من الجداول أرقام •(r) ، (ع) أن النسبة المئوية لآراء السادة الخبراء حول مناسبة العبارات المقترحة للاستبيان قد تراوحت بين ؟\% : . . . 1\% ولقد ارتضي الباحثين نسبة • v \% فأكثر من آراء السادة الخبراء وتم استبعاد العبارات التي لم تحصل علي هذه النسبة ، بالإضافة الي تعديل صياغة بعض العبارات ودمج وحذف العبارات المكررة وغير المفهومة بناء علي آراء السادة الخبراء ، وجدول رقم(0)، (7 ) يوضح مجموع عبارات كل محور قبل وبعد العرض علي الخبراء - 


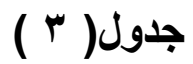 \\ عدد عبارات الاستبيان قبل وبعد العرض على الخبراء \\ (إستمارة آراء العاملين تجاه البرامج الرياضية )}

\begin{tabular}{|c|c|c|c|}
\hline عدد العبارات بعد العرض & عدد العبارات قبل العرض & المحاور الرئيسية & م \\
\hline $1 \varepsilon$ & YI & الأهداف العامة للبرامج الرياضية & 1 \\
\hline ir & $r \cdot$ & التخطيط للبرامج الرياضية & $r$ \\
\hline 9 & 11 & التمويل في البرامج الرياضية & $r$ \\
\hline $1 \varepsilon$ & 17 & (الزمن - التوقيت - البرامج الرياضية & $\varepsilon$ \\
\hline iv & rr & ( الإمكانات بالبرامج الرياضية & 0 \\
\hline $7 V$ & 9. & المجموع & \\
\hline
\end{tabular}

\section{ثانيا : الدراسة الاستطلاعية:}

قام الباحثين بإجراء دراسة استطلاعية علي عينة قوامها كالاتى : عدد( 0 ) إفراد من العاملين بالقناة الثامنة .

من خارج عينة البحث الأساسية وذلك في الفترة من / 1/ إلى $0 / 1 /$ •r • r م •

حيث استهدفت الدراسة الاستطلاعية التعرف علي :

- مدي مناسبة صياغة العبارات لمستوي فهم العينة. 


$$
\text { - إيجأكد من عدم وجود أي عبارات يصعب فهمها - }
$$

ولقد أظهرت نتائج الدراسة الاستطلاعية أن الاستبيان جاء مناسبا من حيث الصياغة واللغة المستخدمة ولم تظهر أي تعليقات توحي بالغموض أو عدم الفهم • ثالثا : المعاملات العملية لاستمارة الاستبيان:

$$
\text { رابعا : المعاملات العلمية : }
$$

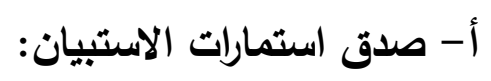

استخدم الباحثين صدق الاتساق الداخلي لحساب معامل الصدق للاستبيان وذلك بهدف التحقق من صدق استمارات الاستبيان حيث تم تطبيق الاستبيان على مجموعة قوامها (0) أفراد من العاملين بالقناة الثامنة من مجتمع البحث وخارج عينة البحث

\begin{tabular}{|c|c|c|c|c|c|}
\hline الإمكانات & التنفيذ & التمويل & التخطيط & الأهداف & العبارة \\
\hline$\because \wedge 9$ & .911 & .9 & .90 & $\cdot .14$ & 1 \\
\hline
\end{tabular}
الأساسية وجدول (ع)) يوضح ذلك :

$$
\text { جدول (๕ ) }
$$

معامل الارتباط بين عبارات الاستبيان والمحور المنتمي إليه

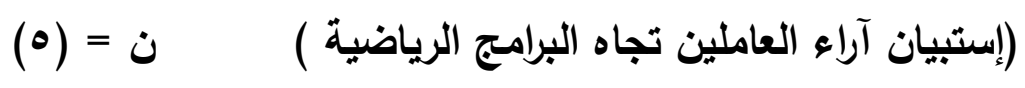




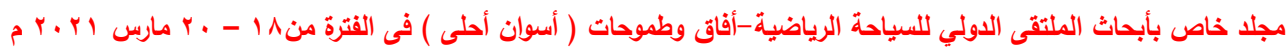
(العدد الثانى)

\begin{tabular}{|c|c|c|c|c|c|}
\hline. $.9 r$ & .90 & .91 &. $.9 \mathrm{~V}$ & $.9 V$ & $r$ \\
\hline .99 &. .91 & .991 &. .91 & .9 & $r$ \\
\hline. .91 & .90 & .991 & .90 & $\cdot .9 r$ & $\varepsilon$ \\
\hline .99 & $\cdot . \wedge \wedge$ &..$\wedge 9$ &. .19 & .94 & 0 \\
\hline..$\wedge 9$ &. .94 & .9 & .99 & $\cdot . \wedge q$ & 9 \\
\hline$\cdot . \Lambda Y$ & $\cdot .9 \leq$ &.$\Lambda V$ &. .91 & .9 & $V$ \\
\hline .99 & .91 & .991 &. .91 &.$\wedge 9$ & $\Lambda$ \\
\hline. .91 & .90 & .997 & $\cdot .9 \varepsilon$ & .94 & 9 \\
\hline .99 & & $.9 \varepsilon$ & $\cdot . \wedge \wedge$ & .9 & 1. \\
\hline.$\wedge q$ & & .9 &. $.9 \mathrm{~V}$ & $\cdot . \wedge 7$ & 11 \\
\hline .99 & &.$\wedge \vee$ & $.9 \mathrm{~V}$ & .98 & Ir \\
\hline .94 & & .91 & .9 & .91 & $1 r$ \\
\hline .99 & & & &.$\wedge 7$ & $1 \varepsilon$ \\
\hline..$\wedge 9$ & & & & & 10 \\
\hline. .94 & & & & & 17 \\
\hline$\cdot . \wedge \wedge$ & & & & & 18 \\
\hline .99 & & & & & 11 \\
\hline
\end{tabular}

يتضح من جداول (ع )أن جميع قيم معاملات الارتباط بين المفردات المنتمية للمحور

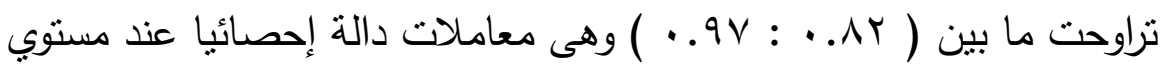




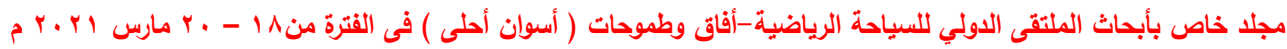
(العدد الثانى)

معنوية(0 . . •) مما يشير إلى اتساق كل عبارة مع المحور الذي تتنمي إليه وبالتالي صدق العبارات في التعبير عن المحور الذي تتنمي إلية 


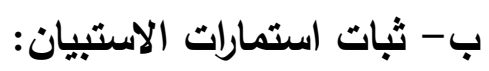

استخدم الباحثين طريق الاختبار وإعادة تطبيقه لحساب معامل الثبات لاستمارات الاستبيان وذلك

بهدف التحقق من ثبات استمارة الاستبيان حيث تم تطبيق الاستبيان على مجموعة قوامها ( 0 ) أفراد من العاملين بالقناة الثامنثمن مجتمع البحث ومن خارج عينة البحث الأساسية وجدول (ه ) يوضح ذلك

\section{(0) (0دول)}

معاملات الارتباط بين التطبيث الأول والثاني لحساب معامل الثبات لاستبيان

$$
\text { رأي العاملين تجاه البرامج الرياضية }
$$

\begin{tabular}{|c|c|c|c|c|c|c|}
\hline \multirow{2}{*}{ الصدق الاتي } & \multirow{2}{*}{ الارتباط معامل } & \multicolumn{2}{|c|}{ التطبيق الثاني } & \multicolumn{2}{|c|}{ التطبيق الأول } & \multirow{2}{*}{ المحور } \\
\hline & & $\varepsilon$ & س س & $\varepsilon$ & س - س & \\
\hline. .91 &. $.9 V$ &..$\leqslant 1$ & $\overline{\varepsilon . V 1}$ & 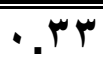 & $\varepsilon .7 q$ & الأهداف العامة \\
\hline. .94 &..$\wedge 7$ &. .70 & $\varepsilon . \leqslant 0$ &. .71 & $\varepsilon . \Delta \mu$ & التخطيط \\
\hline .99 & .991 &. $.7 r$ & $\varepsilon .09$ & .01 & $\varepsilon .00$ & التمويل \\
\hline. .91 & .99 & .09 & $\varepsilon . \leqslant 0$ & .09 & $\varepsilon . \varepsilon V$ & التنفيذ \\
\hline .90 & .94 & $.0 \leqslant$ & $\varepsilon .71$ & $.0 \mathrm{~V}$ & $\varepsilon .09$ & الإمكانات \\
\hline
\end{tabular}

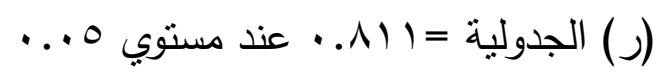

يتضح من جدول(0)أن معامل الارتباط بين التطبيق الأول و الثاني حيت أن قيمة ( ر ) اكبر من ( ر ) الجدولية عند مستوى دلالة (0 . . . مما يثير إلى أن ثبات استمارة الاستبيان كما يدل معامل الصدق على صدق الاستمارة - (الم

رابعا : تطبيق الاستبيان (الدراسة الأساسية) بعد تأكد الباحثين من صدق وثبات استمارات الاستبيان : - 
- استمارة استبيان للتعرف على رأي العاملين بالبرامج الرياضية بالقناة الثامنة. وأصبحت في صورتها النهائية قام الباحثين بنطبيق الاسنبيان في صورته النهائية بحيث كانت الإجابة

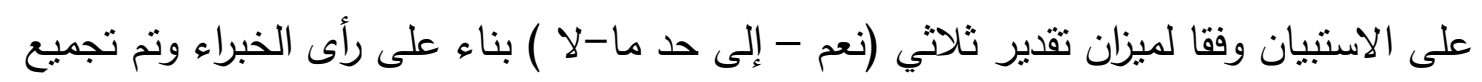
البيانات وجدولتها ومعالجتها إحصائيا .

\section{- المعالجة الإحصائية -}

بعد جمع البيانات وجدولتها تم معالجتها إحصائيا وقد استخدم الباحثين الأساليب الإحصائية:

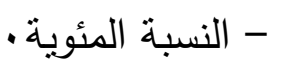

$$
\text { - - معامل الارتباط لبيرسون. - الانحراف المعياري. }
$$

عرض ومناقثة نتائج أراء العاملين بالبرامج الرياضية تجاه البرامج الرياضية بالقتاة الثامنة. 
المحور الأول : الأهداف العامة للبرامج الرياضية

جدول (1)

الارجة المقدرة والنسبة المئوية لأراء عينة البحث في المحور الأول

الأهداف العامة للبرامج الرياضية

\begin{tabular}{|c|c|c|c|c|c|c|}
\hline النسبة & المقدرة & 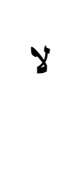 & 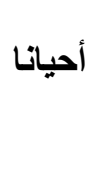 & 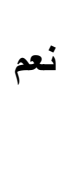 & 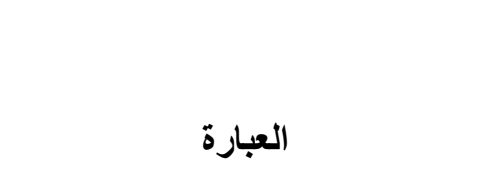 & b \\
\hline 72 & 36 & r & 1. & $\wedge$ & تختلف من برنامج إلي آخر وفق مدل & 1 \\
\hline 96 & 48 & - & r & 11 & تهنم بالارتقاء بالفكر والسلوك & 2 \\
\hline 84 & 42 & - & $\wedge$ & ir & تخلم كافة المستويات والطبقات في & 3 \\
\hline 96 & 48 & • & r & 11 & تخلم الأهداف العامة للرياضة في & 4 \\
\hline 88 & 44 & $\cdot$ & 7 & $1 \varepsilon$ & تساهم في نشر الثقافة الرياضية & 5 \\
\hline 92 & 46 & • & $\varepsilon$ & 17 & تتسم بالمرونة حسب تغيز الإقليم & 6 \\
\hline 68 & 34 & r & ir & 7 & تكافة القضايا الرياضية بالوالمية في عرضية & 7 \\
\hline 36 & 18 & ir & $\wedge$ & - & تراعي الروئيا المستقبلية للرياضة & 8 \\
\hline 20 & 10 & $r \cdot$ & • & - & ترتبط بمصادر التمويل لتنفيذ تلكك & 9 \\
\hline 20 & 10 & $r \cdot$ & - & - & 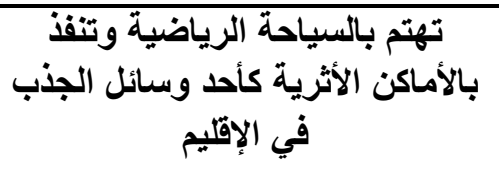 & 10 \\
\hline 28 & 14 & 17 & $\varepsilon$ & • & تهتم بالنواحي التعليمية لكافة & 11 \\
\hline 76 & 38 & • & Ir & $\Lambda$ & تساهم في الكثفي في الإقليم ودعمها المواهب & 12 \\
\hline
\end{tabular}




\begin{tabular}{|c|c|c|c|c|c|c|}
\hline 92 & 46 & . & $\varepsilon$ & 17 & تساهم في دعم المؤسسات الرياضية & 13 \\
\hline 100 & 50 & $\cdot$ & • & $r$. & في تقفي عن نواحي المقترحات لحل المشور و تشاكل & 14 \\
\hline 69.1 & 484 & & & & & \\
\hline
\end{tabular}

- أن النسبة المئوية لأراء عينة العاملين بالبرامج الرياضية في محور (الأهداف العامة للبرامج

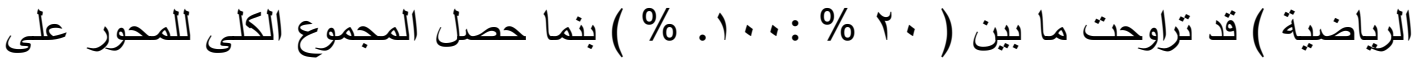

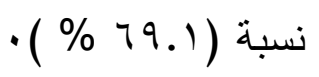

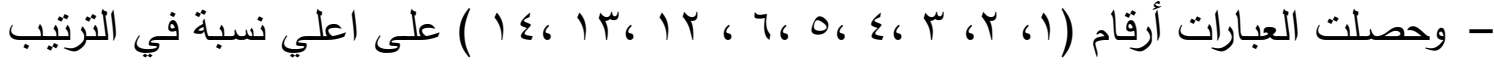

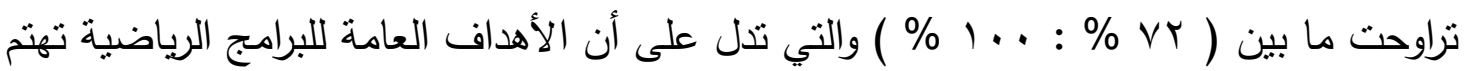
بالارتقاء بالفكر والسلوك وتخدم كافة المستويات والطبقات طبقا للأهداف العامة في الدولة وتتسم الأهداف العامة أيضا بمساهنتها في نشر الثقافة الرياضية وتتغير بالمرونة حسب تبات تغير الأهداف

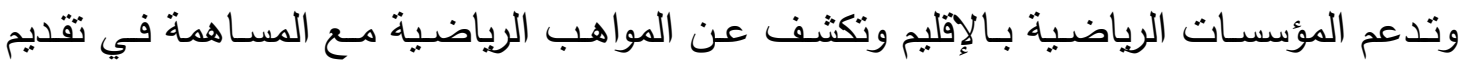
المقترحات لحل المشاكل التي تعترض مسيرة المؤسسات الرياضية بالإقليم ويتفق ذلك مع ما أثنار

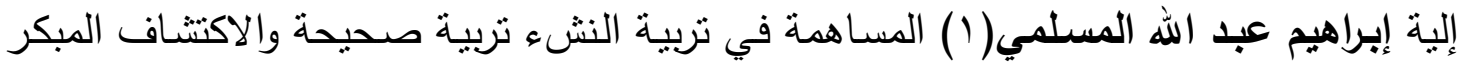

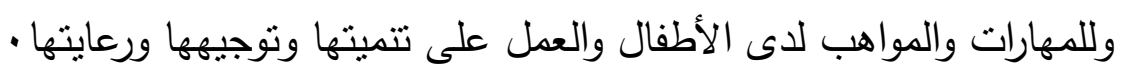

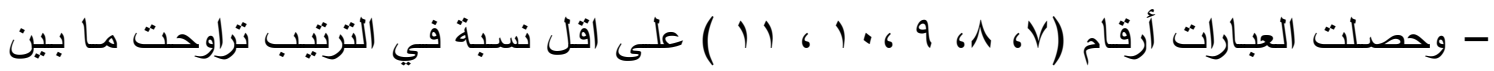

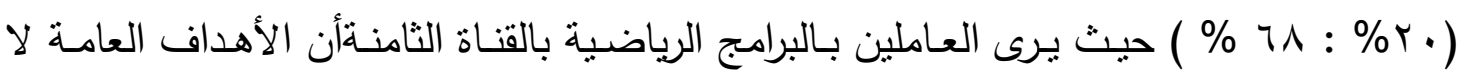

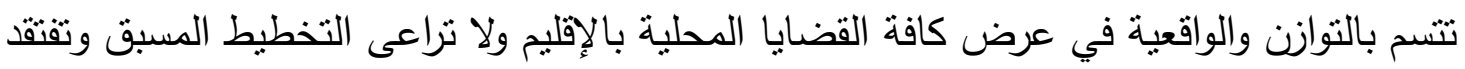

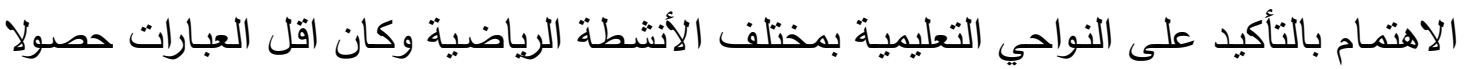

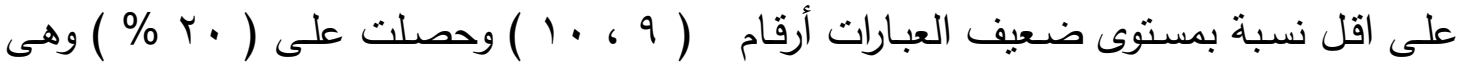

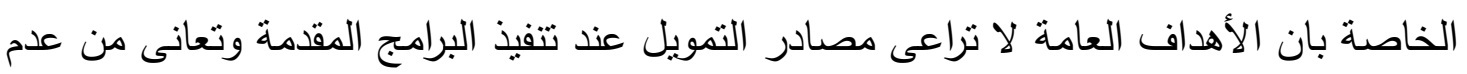
الاهتمام بتتفيذها داخل الأماكن الأثرية كأحد وسائل الجذب في الإقليم وقصور الأهنمام بالئل بالسياحة الرياضية ويرى الباحثين أن مصادر التمويل تعتبر من العناصر الرئيسية لبناء ونظوير البرامج الإهي

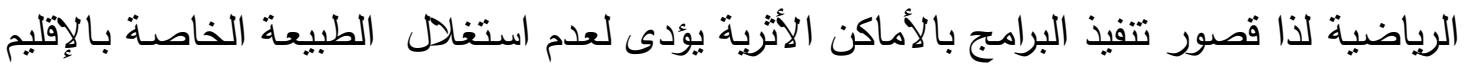

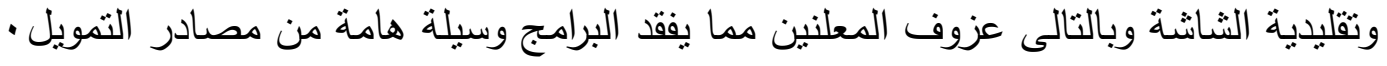




\section{جدول جل}

الارجة المقدرة والنسبة المئوية لأراء عينة البحث في المحور الثاني

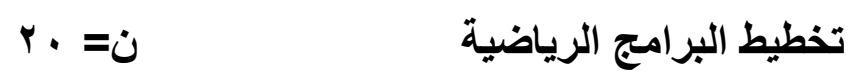

\begin{tabular}{|c|c|c|c|c|c|c|}
\hline النسبة & المقدرة & 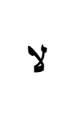 & أحيانا & نعم & العبارة & م \\
\hline 36 & 18 & Ir & $\wedge$ & • & 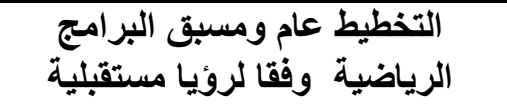 & 1 \\
\hline 28 & 14 & 17 & $\varepsilon$ & - & مشعاركة العاملين بالبرامج الرياضية فيلتيل & 2 \\
\hline 96 & 48 & - & $r$ & 11 & 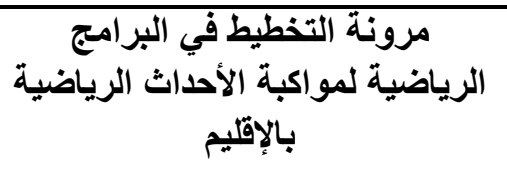 & 3 \\
\hline 88 & 44 & . & 7 & $1 \leq$ & وضع تخطيط جديد للبرامج الزيل والقصور عندية & 4 \\
\hline 20 & 10 & $r$. & • & - & الاستعانة بالخبراء عند التخطيط & 5 \\
\hline 20 & 10 & $r$. & - & - & وضع تخطيط جليد للبرامج الجمهور عندية & 6 \\
\hline 36 & 18 & Ir & $\Lambda$ & . & الأنثطة عند الرياضية التي الاهتمام بكافة بهاة & 7 \\
\hline 20 & 10 & $r$ & • & - & يراعي البعد والتميز البياحي للإقليم البرية & 8 \\
\hline 20 & 10 & $r$. & • & - & 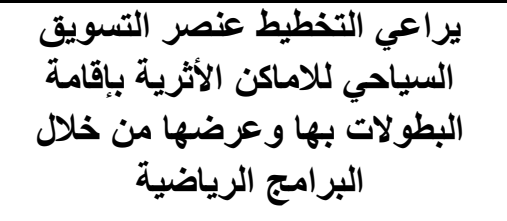 & 9 \\
\hline 20 & 10 & $r$. & • & ' & يراعي عند التخطيط المصادر & 10 \\
\hline 36 & 18 & Ir & $\Lambda$ & • & يراعي عند التخطيط الإمكانات للأجهزة المتوة & 11 \\
\hline 84 & 42 & - & $\Lambda$ & Ir & 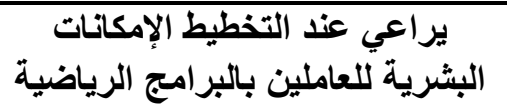 & 12 \\
\hline
\end{tabular}




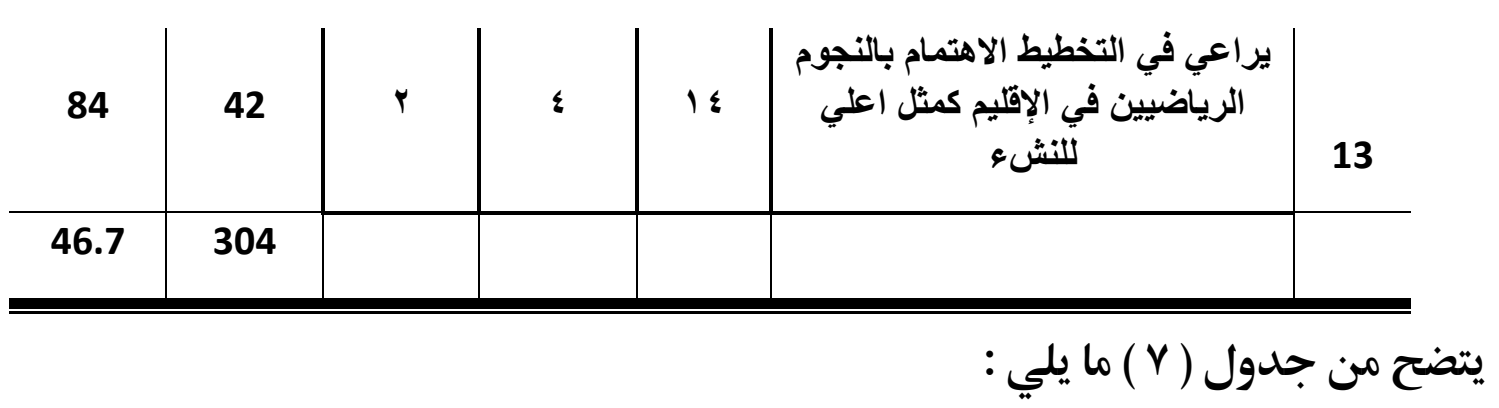

أن النسبة المئوية لأراء عينة العاملين بالبرامج الرياضية في محور ( تخطيط البرامج الرياضية ) قد

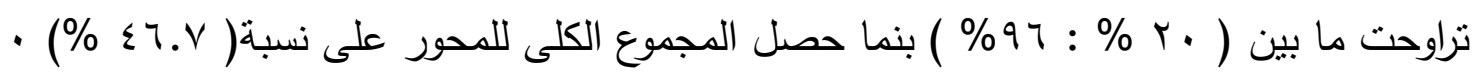

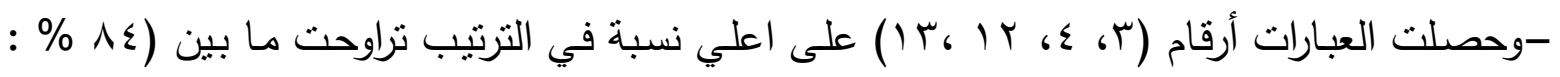

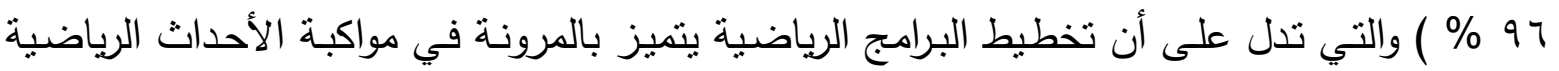
ويمكن معالجة اى خلل أو قصور عند وضع تخطيط جديد للبرامج وهو ما يؤكد على أهمية التخطيط

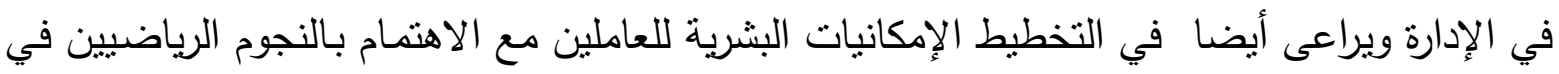

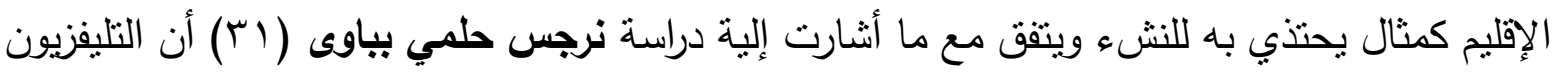

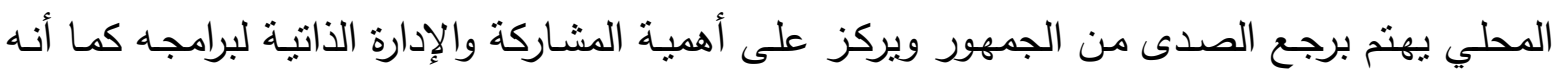

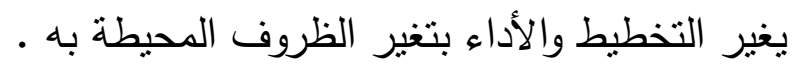

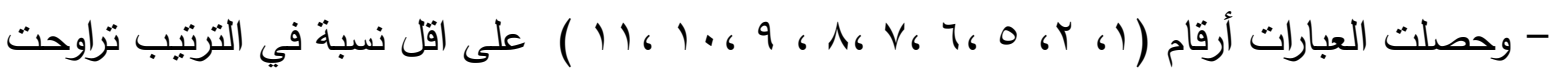

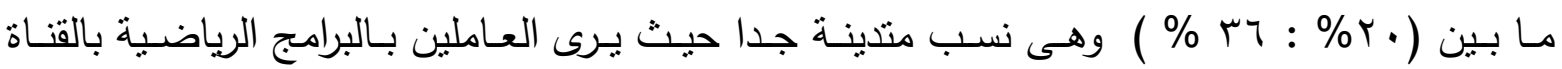

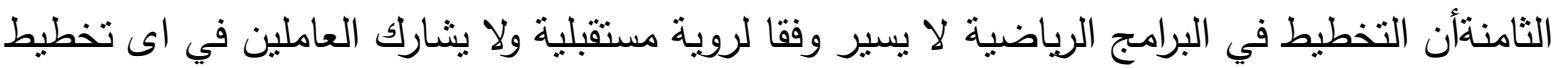

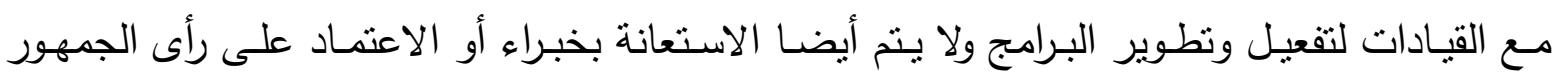

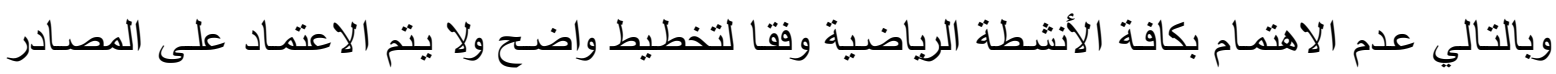

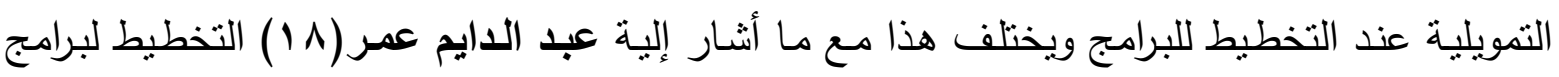
التليفزيون يجب أن يتعلق بوضوح الأهداف التي تقوم البرامج علي خدمنها ومحاولة نوفير الإمكانات المادية والبشرية اللازمة لتنفيذها ووضع الخطط البرامجية التي تحقق هذه الأهداف المرجوة في إطار من النوازن بين رغبات المشاهدين واهتماماتهم واحتياجاتهم من جهة وتحقيق الأهداف الدذكورة من جهة 
جدول (^)

الارجة المقدرة والنسبة المئوية لأراء عينة البحث في المحور الثالث

$$
\text { التمويل في البرامج الرياضية }
$$

\begin{tabular}{|c|c|c|c|c|c|c|}
\hline النسبة & المقدرة & ע & أحيانا & نعم & العبارة & م \\
\hline 20 & 10 & r. & . & . & 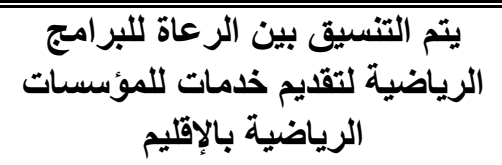 & 1 \\
\hline 28 & 14 & 17 & $\varepsilon$ & · & 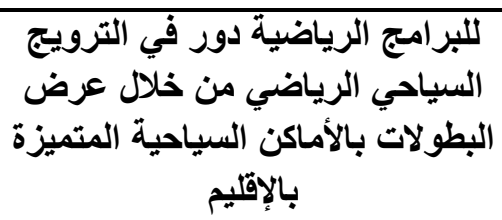 & 2 \\
\hline 20 & 10 & r. & - & · & لرجال الأعمال والمستثمرين دورفية البراضية & 3 \\
\hline 20 & 10 & $r$. & - & . & 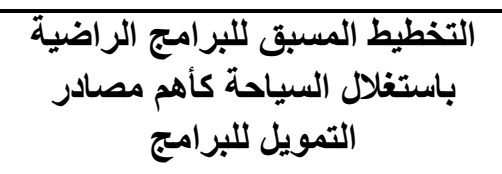 & 4 \\
\hline 32 & 16 & $1 \varepsilon$ & 7 & · & 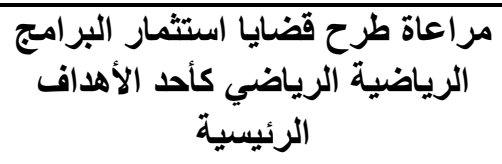 & 5 \\
\hline 32 & 16 & $1 \varepsilon$ & 1 & · & 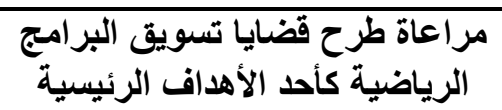 & 6 \\
\hline 20 & 10 & $r$. & . & . & الرياضية لتطوير بآراء العاملئين بالبراميل بالتها & 7 \\
\hline 20 & 10 & $r$. & . & • & 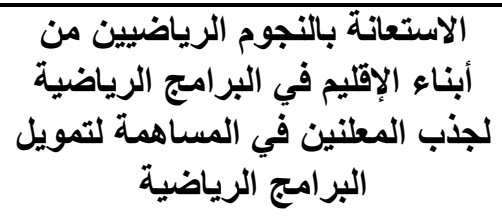 & 8 \\
\hline 20 & 10 & r. & . & · & البرامجانات الريبل وداضية لها وبعد عها في البرض & 9 \\
\hline 25.7 & 116 & & & & & \\
\hline
\end{tabular}


أن النسبة لأراء عينة العاملين بالبرامج الرياضية في محور ( التمويل في البرامج الرياضية) تراوحت ما

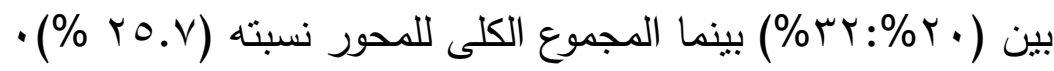

- وحصلت العبارات أرقام (0، ؟) على اعلي نسبة في الترتيب وقدرها ( r r \% )وهى نسبة ضعيفة و تدل على قصور مراعاة طرح قضايا استثمار وتسويق البرامج الرياضية كأحد الأهداف الرئيسية

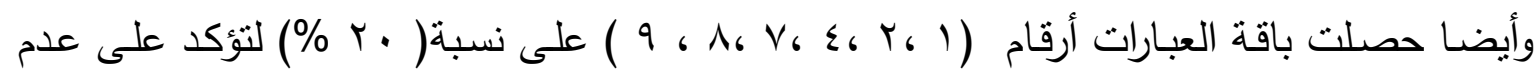

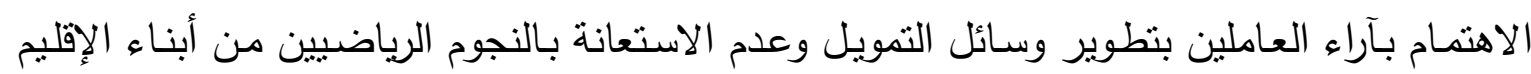
لجذب المعلنين وانخفاض نسبة الإعلانات قبل وداخل وبعد عرض البرامج الرياضية وغياب دور رجال الأعمال والمستثمرين المعلنين في دعم وتمويل البرامج وعدم تسويق برامج السباحة الرياضية

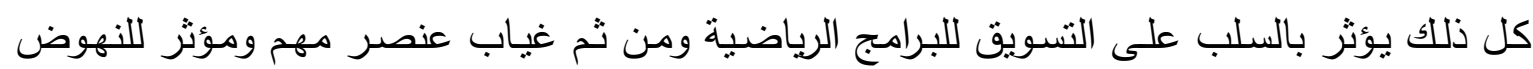
بالبرامج الرياضية

فالتمويل للبرامج الرياضية ضعيف للغاية بالرغم من أهمية الرياضة الأن كمنتج سلعى تستطيع منة

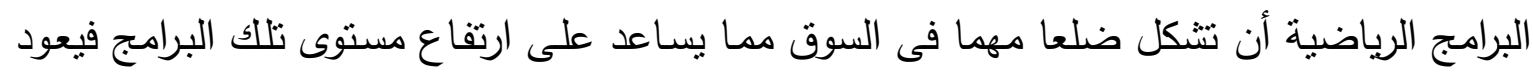
ذللك بالنفع على الحركة الرياضية بالاقليم.

المحور الرابع : تنفيذ البرامج الرياضية

\section{جدول (9)}

الارجة المقارة والنسبة المئوية لأراء عينة البحث في المحور الرابع

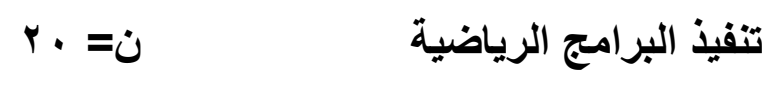

\begin{tabular}{|c|c|c|c|c|c|c|c|}
\hline ألنسبة & 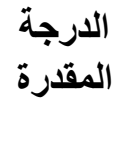 & $\gamma$ & أحيا & نعم & العبارة & 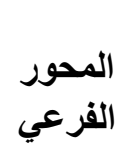 & r \\
\hline 88 & 44 & · & 7 & $1 \varepsilon$ & للملائمة زمن البرامج الرياضية & \multirow{3}{*}{ الزمن } & 1 \\
\hline 36 & 18 & $1 \varepsilon$ & $\varepsilon$ & $r$ & مناطبة الزياضة لكافة المخراحل العمرية اللبرامي & & 2 \\
\hline 84 & 42 & $\cdot$ & $\wedge$ & Ir & مناسبة في نهاية الأسبية البرامج الرياضية والعطلات & & 3 \\
\hline
\end{tabular}




\begin{tabular}{|c|c|c|c|c|c|c|c|}
\hline 20 & 10 & $r$. & ${ }^{\circ}$ & - & تالبرامج فترة زمنية لمشاركة الجمهور في & & 4 \\
\hline 40 & 20 & ir & 7 & r & توقيت عرض البرامج مناسب للجمهور & \multirow{4}{*}{ التوقيت } & 5 \\
\hline 96 & 48 & - & $r$ & 11 & مر محتوي المقادة المقدمة بهر المها الرياضية & & 6 \\
\hline 100 & 50 & - & . & r. & وفتيز أهمية الحدث عرض البرامج الرياضية & & 7 \\
\hline 20 & 10 & r. & . & · & وفتحد تخطيط مسبق عرض البرامج الرياضية & & 8 \\
\hline 100 & 50 & $\cdot$ & $\cdot$ & r. & تتنوع القوالب القنية للبرامج الرياضية & \multirow{7}{*}{ التنفيذ } & 9 \\
\hline 20 & 10 & $r$. & • & · & في الأمساكن البرامج الرياضية المتوفرة أماكن التصوير & & 10 \\
\hline 92 & 46 & . & $\varepsilon$ & 17 & في البرامج الرياضية التخاطب بها الجمهور & & 11 \\
\hline 92 & 46 & - & $\varepsilon$ & 17 & اللصورة في البرامتج الرياضية التكنولوجية الحديثة & & 12 \\
\hline 96 & 48 & - & $r$ & 11 & وفتى هدف البرنامـج تصوير البرامج الرياضية & & 13 \\
\hline 100 & 50 & - & - & r. & مراعاة التنوع في الثكل الفني أثناء & & 14 \\
\hline 70.28 & 492 & & & & & & \\
\hline
\end{tabular}

$$
\text { يتضح من جدول ( } 9 \text { ) ما يلي : }
$$

أن النسبة المئوية لأراء عينة العاملين بالبرامج الرياضية في محور (تتفيذ البرامج الرياضية ) قد تراوحت

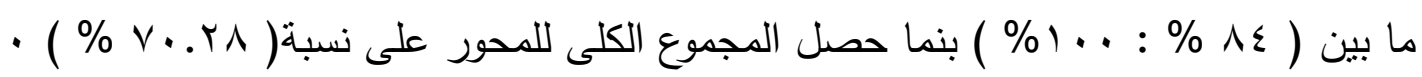
ا- المحور الفرعي الأول : الزمن

وأرقام وعباراته من 1 : ع 


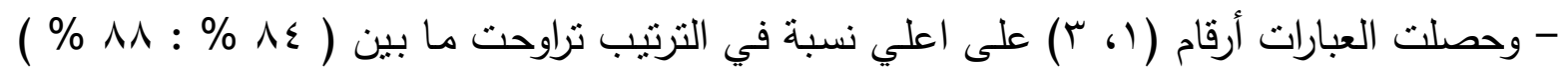
والتي تدل على أن زمن تنفيذ البرامج الرياضية يلاءم المعلومات المقدمة به وان المساحة الزمنية للبرامج الرياضية تتاسب نهاية الأسبوع والعطلات

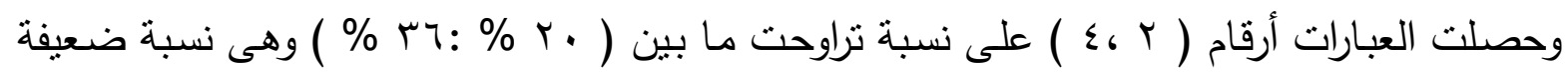
تدل على أن الزمن المخصص للبرامج الرياضية لا يناسب كافة المراحل العمريـة ولا يتم تحديد فترة زمنية محددة لمشاركات الجمهور في البرامج r- المحور الفرعي الثاني : التوقيت

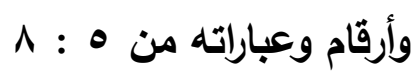

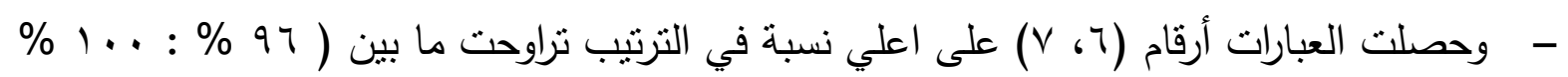

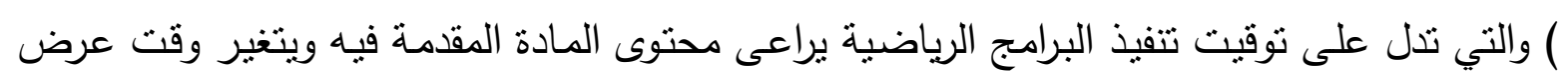

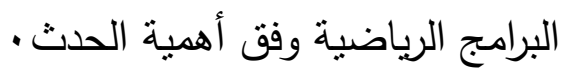

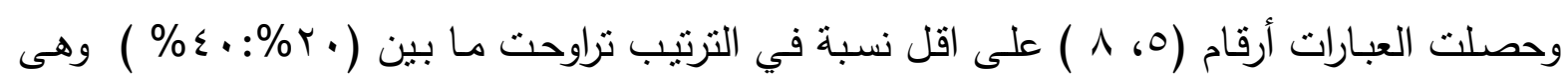

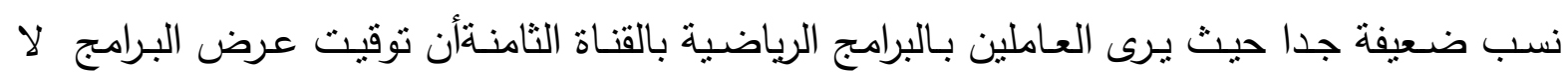

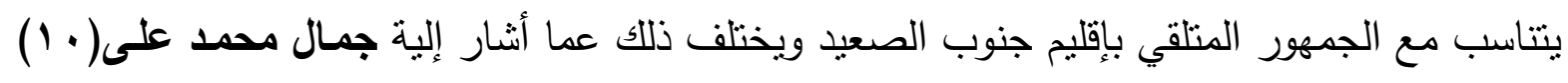
فى أن يقتضي حسن الإدارة إن ينم الاتصسال في الوقت المناسب فإجراء الاتصـال قبل هذا التوقيت

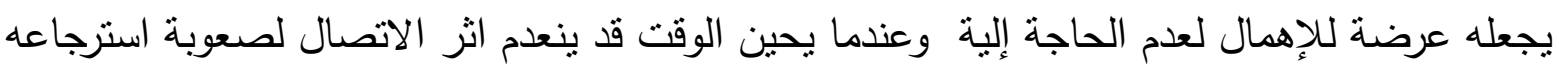

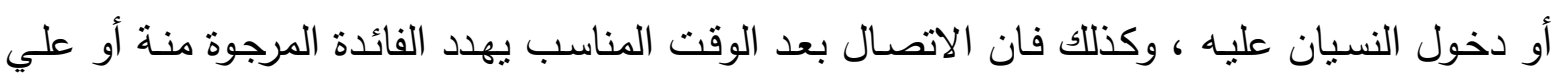
الأقل يقلل من فاعليه الاتصال . - مان.

وأيضا لايتفق ذلك مع محمد معوض إبراهيم (Y^) في أنة يجب أن يراعي في كل دورة برامجية ضرورة

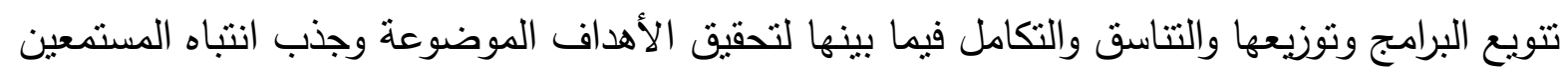

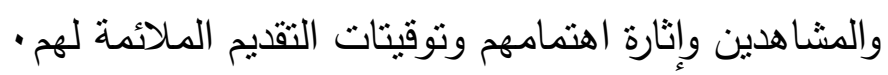

$$
\text { r-المحور الفرعي الثالث : التنفيذ }
$$$$
\text { وأرقام عباراته من } 9 \text { : ك ـ } 1
$$ 


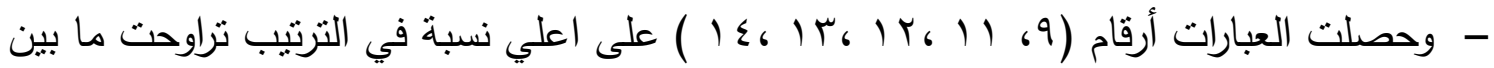

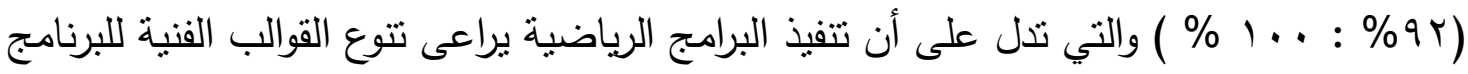
الواحد واختيار اللغة التي يخاطب بها جمهور إقليم جنوب الصعيد وتنتوع أماكن تصوير البرامج الرياضية وفق هدف البرامج المحدد له ولتنفيذ ذلك تستعين بالنواحي التكنولوجية الحديثة لجودة - الصورة التلفزنونية

- وحصلت العبارة رقم (• () على اقل نسبة في التزتيب وهى (•r\%) وهى نسب ضعيفة حيث يرى العاملين بالبرامج الرياضية بالقناة الثامنةأن البرامج الرياضية لا تهتم بالتصوير في ألاماكن السياحية المتوفرة بالإقليم لايتفق ذلك مع سمير محمد حسين(ع 1) موضحا أن من أهم أهداف القنوات المحلية توضيح الأساليب المثلي لاستغلال الإمكانات البيئية المتاحة لخدمة مشروعات التتمية ويختلف فى هذا مع رأى العاملين بالبرامج الرياضية بالقناة الثامنة مما يفقد

$$
\text { جدول (·) }
$$

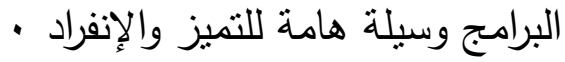

الارجة المقدرة والنسبة المئوية لأراء عينة البحث في المحور الخامس

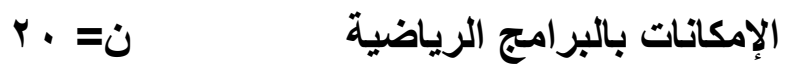

\begin{tabular}{|c|c|c|c|c|c|c|c|}
\hline النسبة & المقرة & $\gamma$ & نايا & نعم & العبارة & الفرعي & p \\
\hline 60 & 30 & $r$ & 17 & r & المبذول الأجور المالية للعاملين مع الجها & \multirow{4}{*}{$\begin{array}{l}\text { إمكانات } \\
\text { مادية }\end{array}$} & 1 \\
\hline 20 & 10 & $r$. & . & - & بتالبر تقديم أجور وبدل سفر للضيوف & & 2 \\
\hline 20 & 10 & $r$. & . & - & 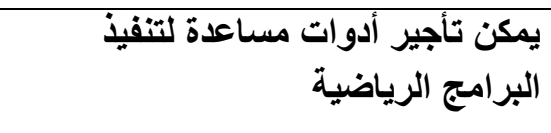 & & 3 \\
\hline 20 & 10 & $r$. & - & • & يمكن تقديم أجور للخبراء الرياضيين & & 4 \\
\hline 68 & 34 & . & 17 & $\varepsilon$ & تظوافر الفنيين المؤهلين بقسم الايكور & \multirow{3}{*}{ 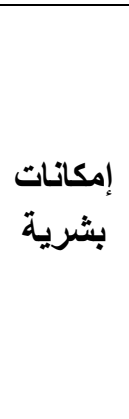 } & 5 \\
\hline 60 & 30 & $r$ & 17 & r & تظوافر الفنيين المؤهلين بقسم الإضاءة البراء & & 6 \\
\hline 92 & 46 & . & $\varepsilon$ & 17 & تظوافر الفنيين المؤهلين بقسم المونتاج البراتج بشكل جيد & & 7 \\
\hline
\end{tabular}




\begin{tabular}{|c|c|c|c|c|c|c|c|}
\hline 100 & 50 & - & . & $r$. & وتطوير شكل البرناد علي مهند الايكور في تنفيذ & & 8 \\
\hline 60 & 30 & $\Lambda$ & $r$ & $\Lambda$ & توافر مهندسي الإضاءة المؤهلين لتنفيذ & & 9 \\
\hline 80 & 40 & . & 1 & 1 & جيد مع التبرامع مع الإدارات المعاونة يتم بشكل & & 10 \\
\hline 100 & 50 & - & • & $r$. & توافر المصورين لتنفيذ البرامج & & 11 \\
\hline 68 & 34 & . & 17 & $\varepsilon$ & 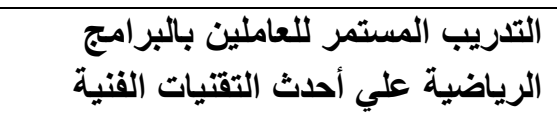 & & 12 \\
\hline 88 & 44 & . & 7 & $1 \varepsilon$ & توافر ماكينات المونتاج الاكترونية & & 13 \\
\hline 56 & 28 & 7 & 1 & $\varepsilon$ & 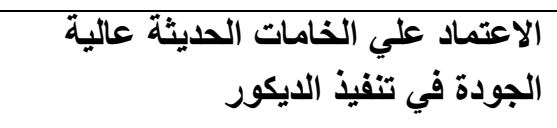 & & 14 \\
\hline 88 & 44 & . & 7 & $1 \varepsilon$ & توافر الكاميرات ووسائل الإضاءة ذات & & 15 \\
\hline 36 & 18 & $1 r$ & $\Lambda$ & - & الاعتماد علي مكتبة الشرائط في توفير & إمكانات & 16 \\
\hline 88 & 44 & . & 7 & $1 \varepsilon$ & تنفيذ البرامجام الأجهزة الالكترونية الحديثة في & & 17 \\
\hline 64.9 & 552 & & & & & & \\
\hline
\end{tabular}

$$
\text { يتضح من جدول (• (1) ) ما يلي : }
$$

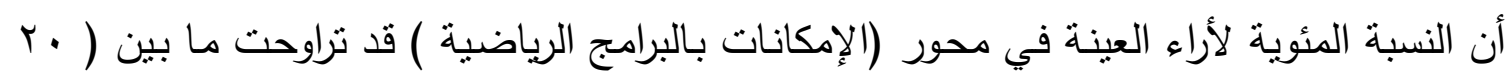

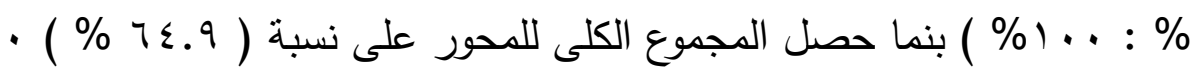
ا- المحور الفرعي الأول : الإمكانات المادية

$$
\text { وأرقام وعباراته من } 1 \text { : ؛ }
$$


- وحصلت العبارة رقم (1) على اعلي نسبة في الترتيب وقدرها ( ج \% ) والتي تدل على أن

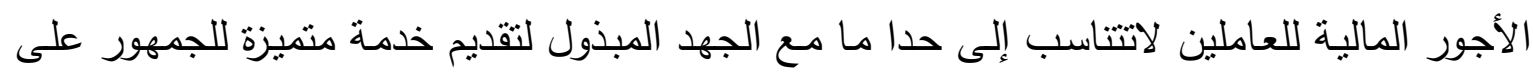

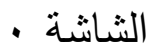

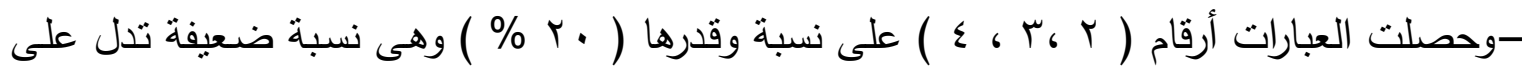

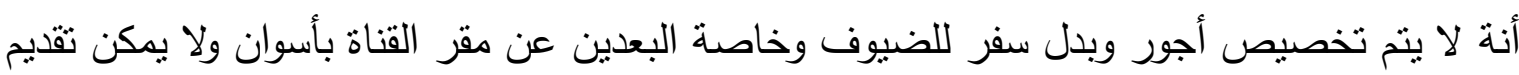

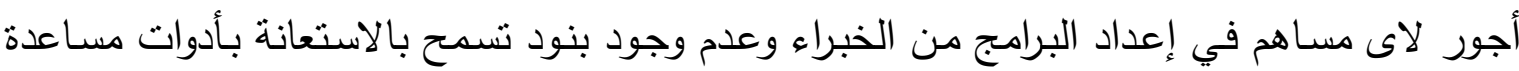

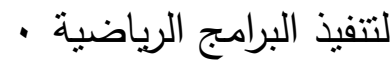
r- المحور الفرعي الثاني : الإمكانات البشرية لئية وأرقام وعباراته من ه : ب أ

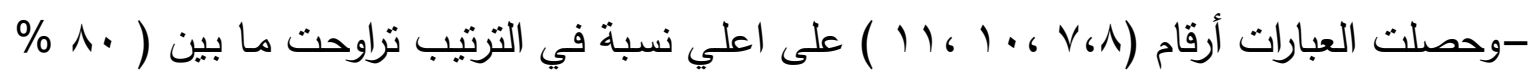

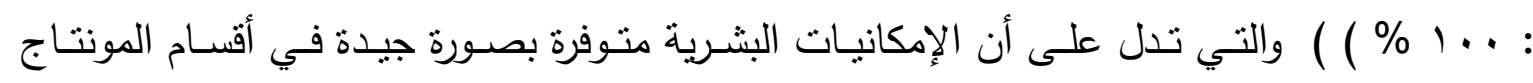
والتصوير والاعتماد على مهندس الديكور في تتفيذ وتطوير شكل البرامج يتم بصورة كبيرة والتعاون

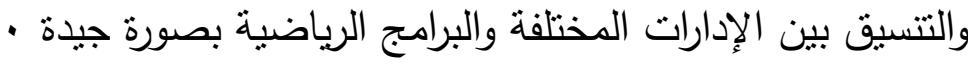

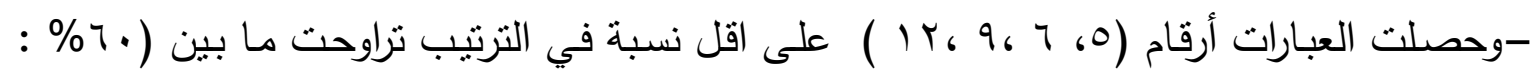

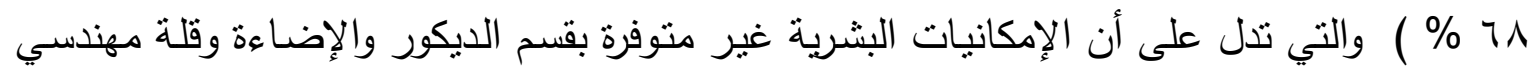
الإضـاءة لتنفيذ وتطوير شكل البرامج بصورة جيدة وان التدريب للعاملين بالبرامج الرياضية لا ينت

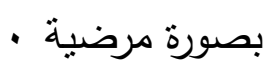

المحور الفرعي الثالث : الإمكانات التقنية

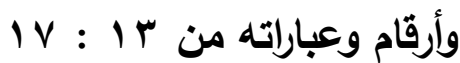

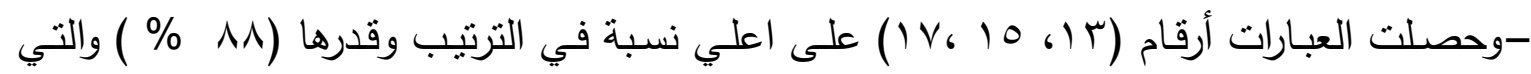

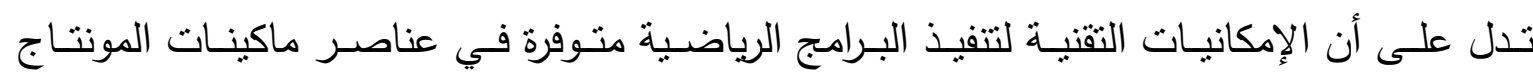
الالكترونبة الحديثة والكاميرات ووسائل الإضاءة ذات الجودة العالية

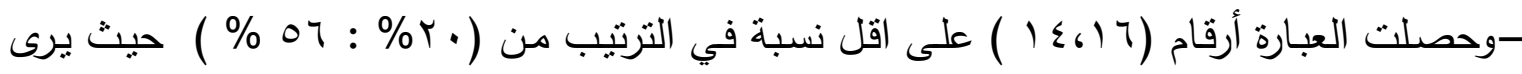

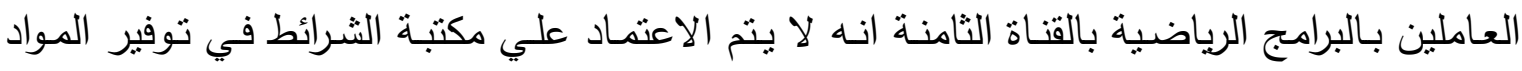
المصورة وهى تختص بالعبارة رقم ( 17 ) التي حصلت على نسبة ضعيفة جدا في حين أن الخامات التهات الحديثة عالية الجودة في تتفيذ الديكور المخصص للبرامج الرياضية تتوافر بصورة منوسطة . 
من خلال العرض السابق يكون الباحثين قد إستطاعوا الإجابة على التسـاؤل الأول للاراسـة وإلخاص

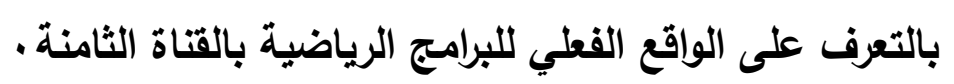

| (الإستتناجات

في ضوء هدف البحث وتحقيقا للإجابـة على تساؤلاته وفى حدود مجتمع وعينـة البحث ومن خلال

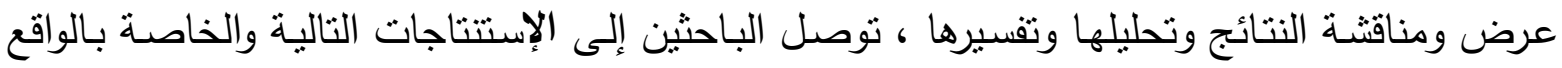

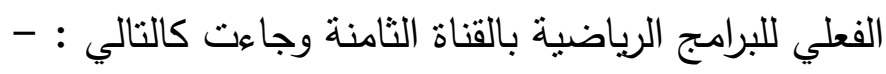

1-الأهداف العامة

- تهتم بالارتقاء بالفكر والسلوك وتعكس قيم المجتمع وتتتوع وفق رغبات كافة المشاهدين • - تساهم في نشر النقافة الرياضية. - الحياد في عرض كافة القضايا الرياضية المحلية بالإقليم. - تأكيد دورها في الكثف عن المواهب الرياضية بالإقليم -

ـ أمـا بالنسبة لوسـائل الجذب في الإقليم كالأمساكن الأثريـة لا تقوم باستخلالها في تتميـة السباحة

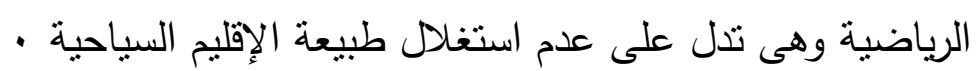

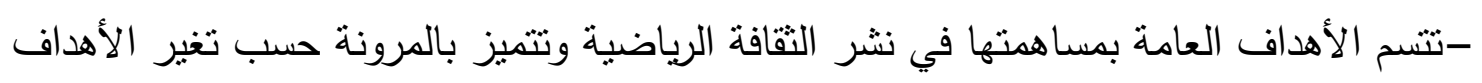

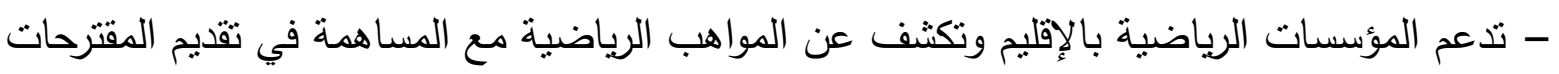

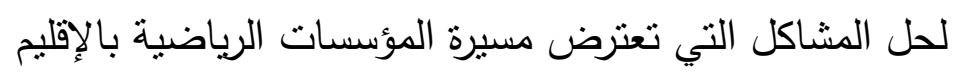
r - محتوى ومضمون البرامج الرياضية

- يتتوع في طرح الموضوعات مع الاهتمام بحسن اختبار الضيف المناسب للموضوع من خلال المادة المقدمة .

- يهتم بالتغطية الثناملة لكافة الأحداث الرياضية الداخلية ولا تهتم بتتاول الأحداث الرياضية الخارجية. -قضية الأزمات الرياضية هي القضية الرئيسية التي تقدمها البرامج الرياضية وتختفي قضايا قوانين

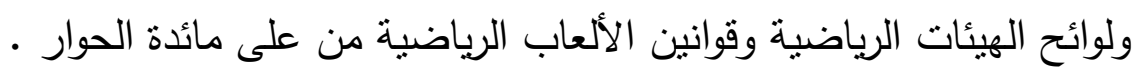

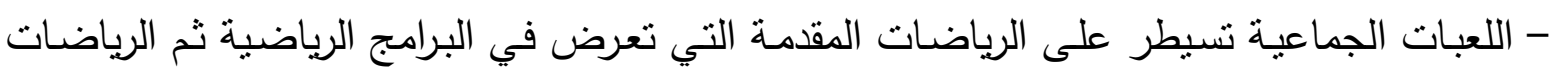

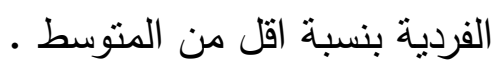


- التخطيط في البرامج الرياضية لا يسير وفقا لروية مستقبلية ولا يشارك العاملين في اى تخطبط مـع القيادات لتفعيل وتطوير البرامج.

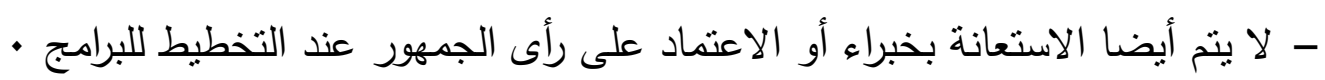

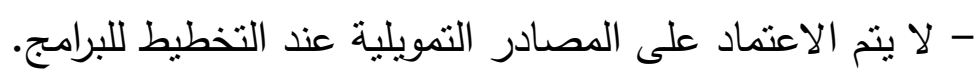

\section{؛ -التمويل في البرامج الرياضية}

- عدم الاهتمام بآراء العاملين بتطوير وسائل التمويل وعدم الاستعانة بالنجوم الرياضيين من أبناء

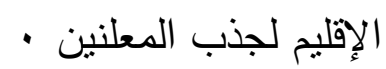

- عدم تسويق برامج السباحة الرياضية يؤثر بالسلب على التمويل للبرامج الرياضية ومن ثم غياب عنصر مهر ومؤثر للنهوض بمستوى الإعلام والتسويق معا ل

\section{ه- ت تنفيذ البرامج الرياضية}

- زمـن تنفيذ البرامج الرياضـية يـلاعم المعلومـات المقدمـة بـهـ وان المسـاحة الزمنيـة للبرامج الرياضية

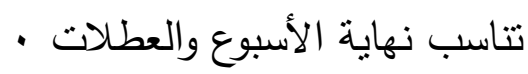

- الزمن المخصص للبرامج الرياضية لا يناسب كافة المراحل العمرية - الجمهور غير راضى عن الفترة الزمنية المسموح بها لمشاركته في البرامج الرياضية. - - توقيت عرض البرامج ل لا يتاسب مع الجمهور المتلقي بإقليم جنوب الصعيد - تتفيذ البرامج الرياضية يراعى تتوع القوالب الفنية للبرنامج الواحد -

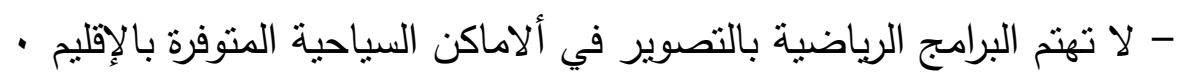

-جميع البرامج الرياضة التي تعرض على شانشة القناة الثامنتبرامج أسبوعية فقط .

\section{צ- الإمكانات بالبرامج الرياضية}

-الإمكانيات البشرية غير منوفرة بقسم الديكور والإضاءة

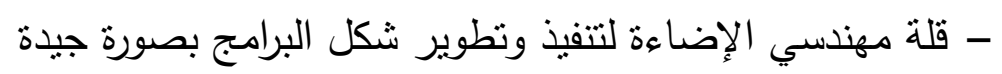

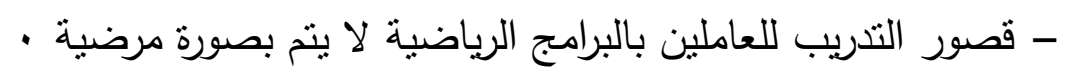
- الإمكانيات التقنية متوفرة في عناصر ماكينات المونتاج الالكترونيـة الحديثة والكاميرات ووسـائل

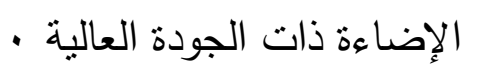

- لا يتم الاعتماد علي مكتبة الثرائط في توفير المواد المصورة • 
- إعـادة صـياغة أهـداف البـرامج الرياضـية لتكـون واضـحة ومحددة للعـاملين على أن تراعـى كافـة • إحتباجات ورغبات المشاهدين

- الإهتمام بتقديم برامج رياضية تحتوى على كافة أنواع الرياضـات دون التركيز على رياضـات بعينها - الاهتمام بالتخطيط المسبق مع ضمان مشـاركة العاملين بالبرامج الرياضية في التخطيط مسع وضع

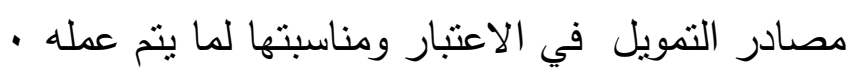
- الاهتمام بوسائل نمويل البرامج مسع تطوير عمل لجان التسويق والإعلان والبحث عن كافة الطرق المناسبة لزيادة مصادر التمويل للبرامج الرياضية خاصة مع ارتفاع نسبة المشاهدين للرياضة . - ضمان توقيت مناسب لعرض البرامج الرياضية يناسب كافة الرغبات على مدار اليوم وزمن مناسب للحلقة الواحدة يراعى المعلومة المقدمة فيه .

- مرعاه استغلال المناطق السياحية والأثرية في التصوير وتسويق البرامج الرياضية من خلالها . - العمل على تخصيص فقرات لمشاركة الجمهور وإبداء رأيه فيما يقدم إلبه تجاه البرامج الرياضية . - لا يجب أن يقتصر مفهوم البرامج الرياضية على مجرد نقل ومناقثـة المنافسات الرياضية فقط ولكن يجب أن تقدم نماذج ومعلومات تساعد المشاهد على التوجه لممارسة الرياضة .

- مرعاه تتوع القوالب الفنية داخل الحلقة الواحدة من البرنامج لضمان عنصر النشويق في الحلقة . - الاهنمـام بالرياضـات التي تختص بالسيدات والأطفال وعمل فقرات خاصـة بهم خـل البرامج بمـا - ميتاسب مع ميولهح ورغباتهم

- تطبيق التصور المقترح لتحسين أداء البرامج الرباضية بالقناة الثامنة r- التصور المقترح لتحسين أداء العاملين بالبرامج الرياضية فى القناة الثامنة : روية التصور المقترحة : 
- يسعى التصور المقترح إلى تحسين وتطوير الأداء داخل البرامج الرياضية بالقناة الثامنة وتحديد

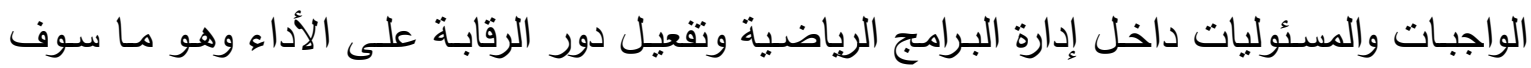

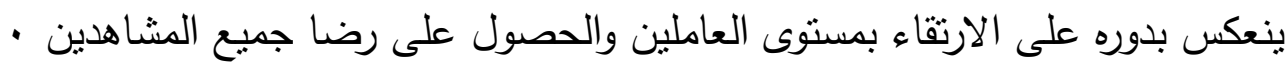

\section{رسالة التصور المقترح :}

- إعداد جيل حديث من العاملين بالبرامج الرياضية مزودين بكافة المعارف والمهارات اللازمة للقيام

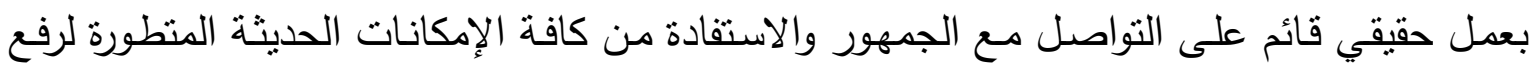
شان شاشة القناة الثامنة .

\section{هاف التصور :}

- العمل على تحسين وتطوير أداء العاملين بالبرامج الرياضية بما يتواكب مـع ضـرورة الإعلام - الحديث

- تقوية الثقة وتدعيمها بين الجمهور المتلقي والعاملين بالبرامج الرياضية لتحقيق متطلبات الجمهور

- محاولة تحقيق النزاهة والحيدة والثفافية الكاملة في تتاول كافة القضايا الرياضية بالإقليم · - تفعيل دور العاملين بالبرامج الرياضية في المشاركة في التخطبط واتخاذ القرار - الارتقاء باللوائح المالية المنظمة للعمل داخل البرامج الرياضية - تأهيل وإعداد د جيل حديث من العاملين بالبرامج الرياضية لديهم الكفاءة والقدرة العقلية على دئ

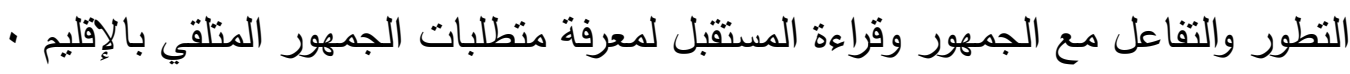

\section{منطلبات التصور المقترحة :}

تتضمن منطلبات التصور المقترح مجموعة من الإجراءات داخل البرامج الرياضية من حيث الثكل

( كيف يقال ) والمضمون ( ماذا قيل ) وتتضمن تللك المنطلبات الخطوات والإجراءات النالية : -

\section{1-الأهداف العامة}

- الأهداف العامة للبرامج الرياضية يجب أن تهتم بالارتقاء بالفكر والسلوك للمشاهد وتنتوع وفق رغبات كافة المشاهدين. - لابد أن نساهم في نشر الثقافة الرياضية وتعكس قيم المجتمع. 
- الحياد في عرض كافة القضايا الرياضية المحلية بالإقليم · - التأكيد على الدور في الكثف عن المواهب الرياضية بالإقليم. - نوافق الأهداف العامة للبرامج الرياضية بالقناة الثامنة مع الأهداف العامة للرياضة في الدولة. - التوازن والواقعية في عرض كافة القضايا المحلية بالإقلي阝 · - عند وضع الأهداف العامة لابد أن تراعى مصادر التمويل للبرامج المقدمة. - تدعم المؤسسات الرياضية بالإقليم مـع المساهمة في تقديم المقترحات لحل الششاكل التي تعترض مسيرة المؤسسات الرياضية بالإقليم. - تتحرك البرامج الرياضية وفق تخطيط محدد و تتسم بالمرونة .

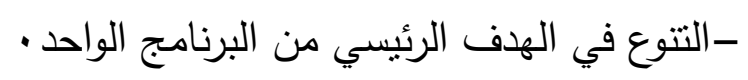
r-تخطيط البرامج الرياضية

- أن يكون تخطيط البرامج الرياضية يتميز بالمرونة في مواكبة الأحداث الرياضية.

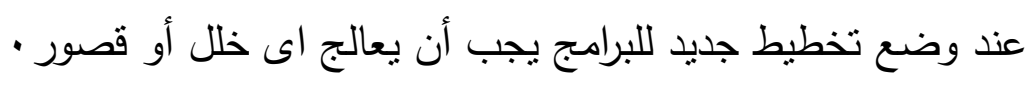
- يراعى في التخطيط الإمكانيات البشرية للعاملين -

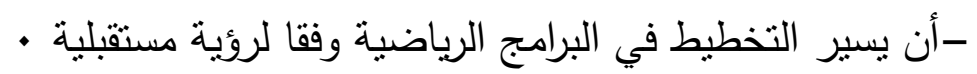
- الاعتماد على مشاركة العاملين في اى تخطيط مع القيادات لتفعيل وتطوير البرامج.

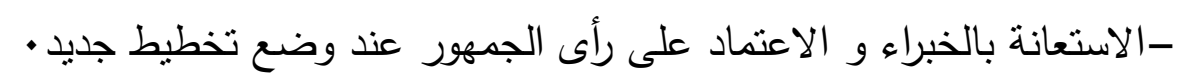

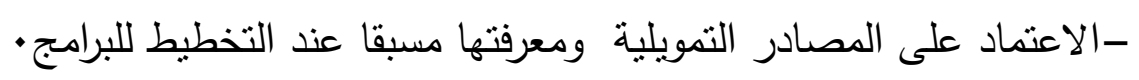
- التخطيط في البرامج الرياضية يراعي البعد والتميز السياحي للإقليم.

\section{r-التمويل في البرامج الرياضية}

- التتسيق بين الرعاة للبرامج الرياضية لنقايم خدمات للمؤسسات الرياضية بالإقليم . - الاهتمام بآراء العاملين بتطوير وسائل التمويل -

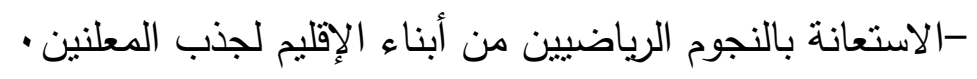

-وضع إستراتجية لعمل الإعلانات بالبرامج الرياضية للاستفادة من عائدها - عمل لجنة لتسويق برامج السياحة الرياضية نظرا لطبيعة الإقليم المتميزة • - الاستعانة بأراء الخبراء المتخصصين في التمويل و الإعلانات و التسويق ل 


\section{ع - محتوى ومضمون البرامج الرياضية}

--التتوع في طرح الموضوعات مع الاهتمام بحسن اختبار الضيف المناسب للموضوع من خلال المادة

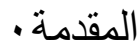

- الاهنمام بالتغطية الثاملة لكافة الأحداث الرياضية الداخلية و الخارجية . - طرح الموضوعات بصورة جيدة ترفع من مستوى المعارف الرياضية . - شـرح القوانين والقواعـ للألعـاب الرياضـية وشـرح وتفسـير اللـوائح والقوانين الخاصـة بالمؤسسـات الرياضية لزيادة الوعي المعرفي للجمهور ل - العدالة في التغطية الإعلامية لكافة محافظات الاقليم -

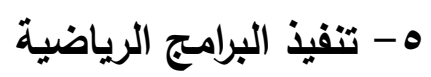

- مراعاة زمن فقرات البرامج الرياضية بما يلاعم المعلومات المقدمة بها - الزمن المخصص للبرامج الرياضية لابد ان يناسب كافة المراحل العمرية . - تخصيص فترة الزمنية لمشاركه الجمهور في البرامج الرياضية . - مراعاة نوقيت عرض البرامج ليتوافق مع رغبات الجمهور المتلقي بإقليم جنوب الصعيد - المحافظة على تتوع القوالب الفنية للبرنامج الواحد واختيار اللغة السهلة التي يخاطب بها جمهور إقليم

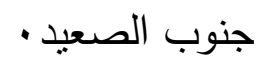
- تتوع أماكن تصوير البرامج الرياضية وفق هدف البرامج المحدد له.

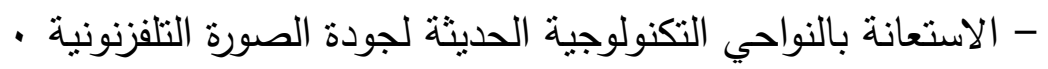
- الاهتمام بالتصوير في الأماكن السياحية المتوفرة بالإقليم - ضمان التتوع فى نوعية المعلومات المقدمة للجمهور - الالتزام بالحياد عند تتاول القضايا التي تقدمها البرامج الرياضية - الاهتمام بتوافق ومناسبة الصور الدصاحبة للمعلومات 1-الإمكانات بالبرامج الرياضية 
ـالاعنماد على الإمكانيات البشرية المدربة في أقسام المونتاج والتصوير والإضـاءة والديكور في تتفيذ وتطوير شكل البرامج.

- التعاون والتتسيق بين الإدارات المختلفة والبرامج الرياضية -

- توفير فرص التدريب للارتقاء بكفاءة العاملين بالبرامج الرياضية والتدريب على الأسـاليب الحديثة

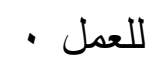

- تخصيص أجور وبدل سفر للضيوف وخاصة البعدين عن مقر القناة بأسوان • - توفير الإمكانيـات الثقنيـة في عناصـر ماكينات المونتاج الالكترونيـة الحديثة والكاميرات ووسـائل الإضضاءة ذات الجودة العالية.

-تحديث مكتبة الثرائط للاعنماد عليها في توفير المواد المصورة.

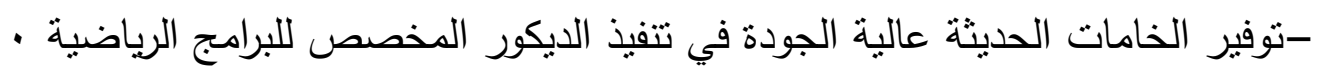
-

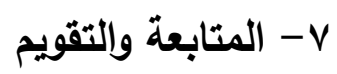

في تلك الفترة من المتابعة للبرامج يتم التعرف على نواحي الضـف والقوة داخل البرامج الرياضية

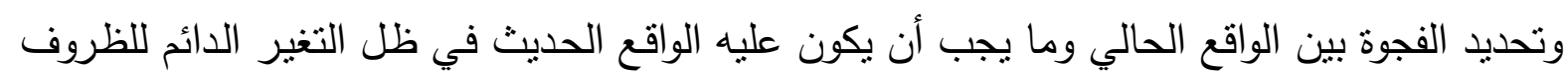

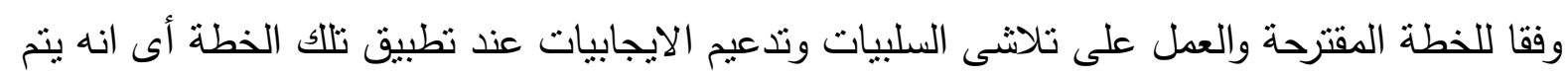

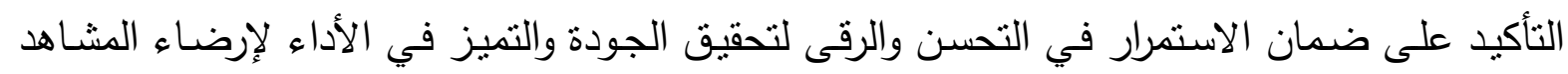

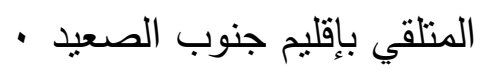

ويهذا ومن خلال العرض السابق يكون الباحثين قـ إستطاعوا الإجابـة على التساؤل الثانى للاراسة والخاص بوضع تصور مقترح لتحسين أداء البرامج الرياضية بالقتاة الثامنة .

\section{المراجع العربية والأجنبية}

أولا : المراجع العربية

1 - إبراهيم عبد الله المسلمي: الراديو والتليفزيون وتتمية المجتمع المحلي ، دار الفكرالعربى ل للنشر والتوزيع، القاهرة ، 997

r- إبراهيم عبد الله المسلمي : الراديو والتليفزيون الإقليمي، العربي للنشر ،القاهرة ، 1997 م. 
ب- اتحاد الإذاعة والتليفزيون :الكتاب السنوي،اتحاد الإذاعة والتليفزبون،القاهرة، ـ99 ام. ع -أحمد حسن بسيونى: دور وسائل الإعلام المحلية في تكوين المعرفة الرياضية لدى طلاب جامعة المنيا، رسالة ماجستير، كلية التربية|لرياضية، جامعة المنيا، ع . . ب م ه- أحمد ماهر فتحى : ثقويم البرامج الرياضيه بالقناة السادسه بتليفزيون وسط الدلتا،رسالة

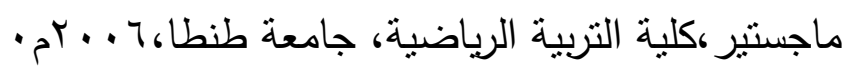
צ - أشرف منير صبري : بناء إستراتيجية للبرامج الرباضية بالتليفزبون المصري ، رسالة دكتوراه ، كلية التزبية الرياضية للبنين ، جامعة القاهرة، 999 (م.

V-الكتاب السنوي:اتحاد الإذاعة والتليفزيون، دارالجمهورية للطباعة والنشر، القاهرة، ع . . بم . 1- أيمن محمد الهنداوي : تحليل برامج التليفزيون الرياضية وآثارها علي نشر الوعي الرياضي،رسالة ماجستير ،كلية التربية الرياضية، جامعة طنطا، ا ـ . بم •

9- أيمن محمد الهنداوي :الإعداد المهني والتوصيف الوظيفي لمعدي البرامج الرياضية

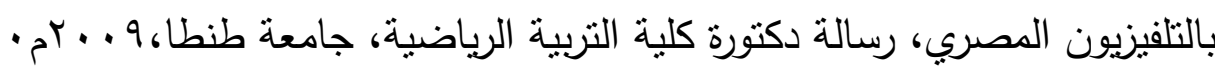
• 1 - جمال محمد علي : التتمية الإدارية في الإدارة الرياضية والإدارة العامة ، مركز الكتاب للنشر ، ط 1 ، القاهرة ، 1 . . ب م •

ا ا- حسام الاين السيد المرسي :دور وسائل الإعلام الجماهيرية في نشر الثقافة الرياضية لدي طلاب بعض الجامعات المصرية ، رسالة ماجستير ، كلية التربية الرياضية ، جامعة طنطا

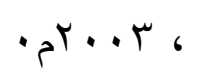

r ا - حسن احمد الشافعي وآخرون: العلاقات العامة في التربية الرباضية ،مكتبة ومطبعة الإشعاع ،القاهرة ،999

ب ا - دينا كمال محمود عوض الله : إدارة الجودة الثاملة كمدخل لتطوير البرامج الرياضية بالتلفيزيون المصري ،دراسة تطبيقية على قناة النيل للرباضة ، رسالة ماجستير ، كلية التربية

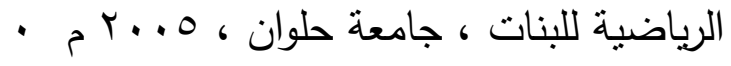

ـ ا - سمير محمد حسين:الإعلام والاتصال بالجماهير والرأي العام،عالم الكتب،القاهرة، 99 (م 


$$
\text { 10 - صالح أبواصبع: قضايا إعلامية ،دار البيان،دبي، •99 ام • }
$$

7 ا - طلحة حسام الدين وآخرون:مقدمة في الإدارة الرياضية،مركزالكتاب للنشر ،القاهرة، ـ99 ام • IV العربية )،دار الفكر العربي ،القاهرة، 990 ام.

1 ا - عبد الدايم عمر حسني:إنتاج البرامج التليفزيونية ،الدار القومية العربية للنشر،ط ،

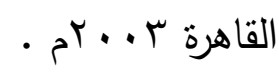

9 1 - عبد الفتاح أبو معال:اثر وسائل الإعلام علي الطفل ،الثروق للنشر والتوزيع،ط

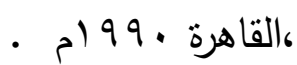

• ץ- عبد المجيد شكري:الإعلام المحلي رؤية مستقبلية ،دار الفكر العربي للنشر والتوزيع

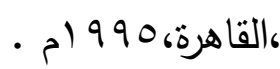

ا Y- عصام الدين بدوي محمد :موسوعة التنظيم و الإدارة في التربية البدنية و الرياضية ، دار الفكر العربي ، القاهرة ، ( . . م م •

r r -علاء الاين أحمد متولي : دور الإذاعة المرئية المحلية فئ تتمية الوعي الرياضي في نشاط السباحة لتطوير مجال السياحة و العلاج و الترويح ، رسالة

دكتورة كلية التربية الرياضية للبنين، جامعة الإسكندرية، ج · . . م

rץ- علي طاهر إسحاق :العلاقة بين التعرض للبرامج الرياضية بالراديو والتليفزيون والمعرفة الرياضية للجمهور المصري ، رسالة ماجستير ، كلية الإعلام ،جامعة القاهرة ، ؛ . . م. بـ. ـ ץ- ماجي الحلواني حسين :مدخل الفن الإذاعي والتليفزبوني و الفضائي ، عالم الكتب ، القاهرة . $r$...

ه - مجدي عبد الكريم حبيب:التقويم والقياس في التربية وعلم النفس،طبعة أولي ،مكتبة النهضة المصرية،القاهرة، 997 (م

جr- مجلة الفن الإذاعي : العدد ع ( اكاتحاد الإذاعة والتليفزبون ،القاهرة 990 ام . rV - محمد محمد الحماحمي:الرياضة للجميع بين الفلسفة والتطبيق، مركز الكتاب للنشر ، 


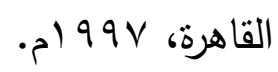

^ץ- محمد معوض إبراهيم :إنتاج البرامج الإذاعية والتليفزبونية،جامعة الكوبت،الكويت - م) $99 \Lambda_{6}$

9 - محمد نصر مهنا : في تتظير الإعلام ، مؤسسة شباب الجامعة ، الإسكندرية ، 9 . . rم • • • - مني سعيد الحديدي، سلوى إمام علي: الإعلام والمجتمع،الدار المصرية اللبنانية ،القاهرة $>_{p} r \cdot . \leqslant$

اس- نرجس حلمي بباوى :استخدام الفيديو في التتمية الزراعية ، دراسة نظرية و تحريرية عن دور الفيديو في توعية المزارعين المصربين ، رسالة دكتوراه ، كلية الإعلام ، جامعة القاهرة، 999 (م

ץT- وليد عبد الفتاح محمد:دراسة تقويمية للبرامج الرياضية بالقناة الثانية بالتليفزيون المصري ، رسالة ماجستير ، كلية التربية الرياضية للبنين ، جامعة حلوان V • . بم.

\section{ثانيا : المراجع الأجنبية:}

33-Chen.T: Influence of sport media on teenaged students sports participation 'Journal of shanhai, physical.education institute, 1996

34-Patrick Richard : Public television and high performance sport in canda , PHD, carleton university canda ,1995

35-Shifflett,B.\&Revelle R.: Gender equity in sports media coverage, Journal of sport and social issues, May , 1994

36-Shih.chih pin: Astudy of the Relationship Between Media Coverage, Audience Behavior and sporting Events,EDD ,University of Northern Colorado,1998. 